\title{
Limits of Activity: Weakly Coordinating Ligands in Arylphosphinesulfonato Palladium(II) Polymerization Catalysts
}

\author{
Boris Neuwald, Franz Ölscher, Inigo Göttker-Schnetmann, and Stefan Mecking* \\ Chair of Chemical Materials Science, Department of Chemistry, University of Konstanz, 78464 Konstanz, Germany
}

\begin{abstract}
The coordination strength of various phosphine oxides $\mathrm{OPR}_{3}$ toward the olefin polymerization catalyst $\left(\mathrm{P}^{\wedge} \mathrm{O}\right) \mathrm{PdMe}\left(\mathrm{P}^{\wedge} \mathrm{O}=K^{2}-\mathrm{P}, \mathrm{O}-\mathrm{Ar}_{2} \mathrm{PC}_{6} \mathrm{H}_{4} \mathrm{SO}_{2} \mathrm{O}\right.$ with $\mathrm{Ar}=2$. $\mathrm{MeOC}_{6} \mathrm{H}_{4}$ ) as compared to that of dmso has been determined. Equilibrium constants $K_{\mathrm{L}}$ for the reaction 1-dmso $+\mathrm{L} \leftrightarrows 1-\mathrm{L}+$ dmso range from 3.5 for electron-rich $\mathrm{OPBu}_{3}$ to $10^{-3}$ for

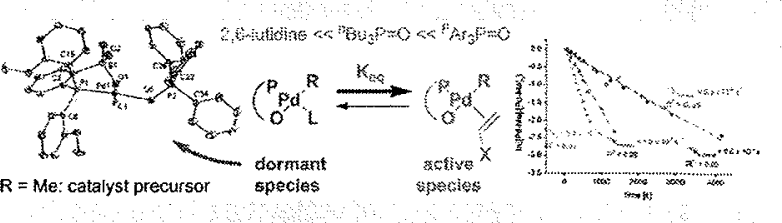
electron poor $\mathrm{OP}\left(p-\mathrm{CF}_{3} \mathrm{C}_{6} \mathrm{H}_{4}\right)_{3}$. Complexes derived from more strongly coordinating phosphine oxides, lie. $\left[\left(\mathrm{P}^{\wedge} \mathrm{O}\right) \mathrm{PdMe}(\mathrm{L})\right]$ $\left(1-\mathrm{L} ; \mathrm{L}=\mathrm{OPBu}, \mathrm{OPOCt}, \mathrm{OPPh}_{3}\right.$ ) have been isolated and fully characterized. Additionally, $1-\mathrm{OPBu} \mathrm{u}_{3}$ and 1 -OPPh $\mathrm{O}_{3}$ were analyzed by $\mathrm{X}$-ray diffraction analyses. Complexes denived from weakly coordinating phosphine oxides have eluded isolation due to loss of phosphine oxide and formation of barely soluble multinuclear palladium complexes $1_{n}$ by bridging coordination of the sulfonate group to various $\mathrm{Pd}$ centers. Hence, the ( $\left.\mathrm{P}^{\wedge} \mathrm{O}\right) \mathrm{PdMe}$ fragment 1 exhibits an intrinsic limitation with respect to coordination of weak donors. Species 1 generated in situ in the absence of additional ligand (L) has been identified in homo and copolymerization experiments as well as NMR insertion studies as the most active possible catalyst. Since 1 is generated from the easily available precursor $\left.\left[\{(1-\mathrm{Cl})-\mu-\mathrm{Na}\}_{2}\right)\right]$, these findings give rapid access to highly active $\left(\mathrm{P}^{\wedge} \mathrm{O}\right) \mathrm{PdMe}$ catalysts.
\end{abstract}

$\mathrm{T}_{\mathrm{p} \text { herle }}$ he catalytic insertion polymerization of ethylene and propylene is one of the most well-studied chemical reactions. In terms of application, it is employed for the production of more than 70 million tons of polyolefins annually. ${ }^{1}$ In contrast, the insertion polymerization of polar-substituted vinyl monomers has long remained elusive. In the past few years major breakthroughs in the field of copolymerization of these monomers with ethylene have been achieved with neutral $\mathrm{Pd}$ (II) phosphinesulfonato catalysts, which were first reported by Drent et $\mathrm{al}^{2-4}$ Among the most remarkable examples are copolymerizations of ethylene with acrylonitrile, ${ }^{5,6}$ vinyl acetate, ${ }^{7}$ and acrylic acid. ${ }^{8}$

The coordination strength of the monodentate ligand $L$ in catalyst precursors $\left[\left(\mathrm{P}^{\wedge} \mathrm{O}\right) \mathrm{PdMe}(\mathrm{L})\right]\left(1-\mathrm{L} ; \mathrm{P}^{\wedge} \mathrm{O}=\kappa^{2}-\mathrm{P}, \mathrm{O}\right.$. $\mathrm{Ar}_{2} \mathrm{PC}_{6} \mathrm{H}_{4} \mathrm{SO}_{2} \mathrm{O}$ with $\left.\mathrm{Ar}=2-\mathrm{MeOC}_{6} \mathrm{H}_{4}\right)$ has a major impact on the catalytic activity in homo- and copolymerizations, given the preequilibration $\left(\mathrm{P}^{\wedge} \mathrm{O}\right) \mathrm{PdR}(\mathrm{L})+$ monomer $\leftrightarrows\left(\mathrm{P}^{\wedge} \mathrm{O}\right) \mathrm{PdR}$ (monomer) $+\mathrm{L}$ which accompanies the chain growth. Thus, more strongly coordinating ligands shift the equilibrium toward the dormant species 1-L. ${ }^{9}$ So far, monodentate ligands, e.g. $\mathrm{PPh}_{3}$, tmeda, pyridine, 2,6-lutidine, dmso, and derivatives thereof have been used., 10-14 Alternatively, bidentate carbon-based ligands, e.g. $\eta^{3}$-allyl or $\eta^{1}, \eta^{2}$-2-methoxycyclooct-5-enyl, are suitable precursors to initiate chain growth.
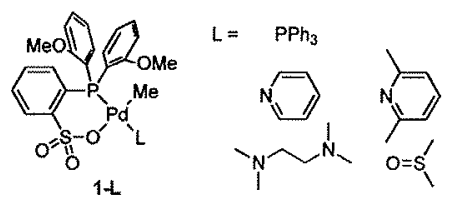

By comparison to the aforementioned $\mathrm{N}$ - and P-based ligands, dimethyl sulfoxide (dmso) binds less strongly to the metal center and is more readily displaced by olefinic substrates. This enabled homooligomerization of methyl acrylate (MA) and the isolation of ethylene-methyl acrylate copolymers with more than $50 \%$ MA incorporation. ${ }^{13,17}$ Here, the weak coordination strength of dmso permitted polymerization at low ethylene pressures and thus high $\mathrm{MA}$ /ethylene ratios. However, limitations for activities and incorporation in co- and homopolymerization experiments with acrylates employing the phosphinesulfonato $\mathrm{Pd}(\mathrm{II})$ catalyst system arise from the six-membered $\kappa^{2}-\mathrm{C}, \mathrm{O}$ chelates $\left[\left(\mathrm{P}^{\wedge} \mathrm{O}\right) \mathrm{PdCH}\right.$ (R) $\mathrm{CH}_{2} \mathrm{CH}(\mathrm{C}(\mathrm{O}) \mathrm{OMe}) \mathrm{CH}_{2} \mathrm{R}^{\prime}$ ]. These six-membered chelates are formed by (co)monomer insertion after a $\mathrm{MA}$ insertion. The coordination strength of the carbonyl oxygen in these chelates is comparable to that of dmso. ${ }^{18}$ For completeness it should be mentioned that entirely "base-free" species of the molecular composition [( $\left.\left.\mathrm{P}^{\wedge} \mathrm{O}\right) \mathrm{PdMe}\right]$ have been isolated $^{12,18,19}$ or synthesized in situ by abstraction of $\mathrm{L}$ from $\left(\mathrm{P}^{\wedge} \mathrm{O}\right) \mathrm{PdMe}(\mathrm{L})^{\mathrm{S}, 16,18,20-22}$ However, so far no improved polymerization activities in comparison to those of "basecoordinated" compounds have been reported. For in situ activated catalysts this might be due to incomplete activation or side reactions by activation reagents or catalyst precursors. $5,16,20$ For isolated material the reported low solubility likely renders part of the catalyst inactive. 18,23

The significantly higher activity observed with dmso- vs pyridine-coordinated catalyst precursors suggests studies of further more weakly coordinating ligands. Phosphine oxides $\left(\mathrm{O}=\mathrm{PR}_{3}\right)$ as a ligand class lend themselves to this purpose, as 
they are easily accessible from the corresponding phosphines and exhibit a defined coordination site at the oxygen atom. Furthermore, a great variety of phosphines are commercially available and allow for electronic and steric fine tuning. While chelating, hemilabile ligands $\left(\mathrm{X}^{\wedge} \mathrm{O} ; \mathrm{X}=\mathrm{N}, \mathrm{P}, \mathrm{O} ; \mathrm{O}=\right.$ phosphine oxide) and especially the phosphine-phosphine oxide ligands have attracted much attention in homogeneous catalysis, ${ }^{24-28}$ the application of monodentate tertiary phosphine oxides in homogeneous catalysis is rare, ${ }^{29-33}$ even though coordination toward metal centers has been well studied. ${ }^{34}$

\section{RESULTS AND DISCUSSION}

Coordination Strength of Phosphine Oxides. Since the coordination strength is influenced by steric as well as electronic properties, both parameters should be varied independently. Here, the cone angle $\theta$ and the electronic parameter $\chi^{35}$ of the corresponding phosphines enable an educated selection of phosphine oxides. ${ }^{36}$ For this study we chose $\mathrm{OPBu}_{3}$, OPOct $_{3}, \mathrm{OPPh}_{3}, \mathrm{OP}(o-\mathrm{Tol})_{3}$, and $\left.\mathrm{OP}\left(p-\mathrm{CF}_{3} \mathrm{C}_{6} \mathrm{H}_{4}\right)_{3}\right)^{36-38}$ for which $\theta$ and $\chi$ parameters have been reported, as well as the even more electron deficient $\mathrm{OP}\left(3,5-\left(\mathrm{CF}_{3}\right)_{2} \mathrm{C}_{6} \mathrm{H}_{3}\right)_{3}$ (Figure 1).

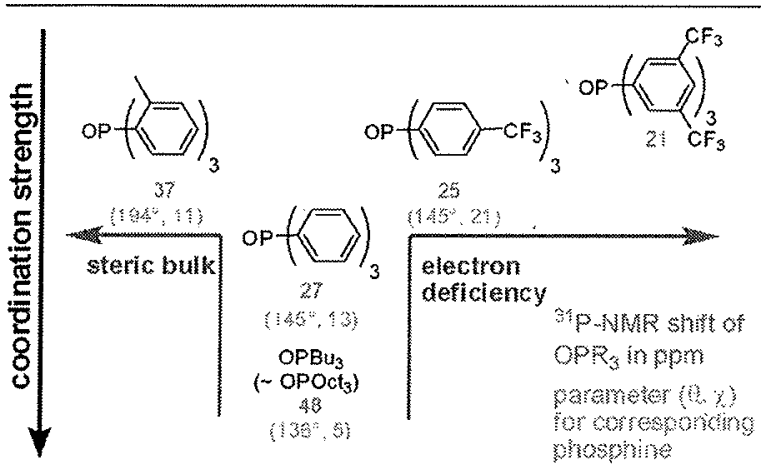

Figure 1. Coordination strength of phosphine oxides based on the parameters $\theta$ and $\chi^{35}$ of the corresponding phosphines. ${ }^{36,37}$

Phosphine oxides not available commercially were easily synthesized by phosphine oxidation with $\mathrm{H}_{2} \mathrm{O}_{2}$ (cf. the Supporting Information).

With regard to the electronic properties, a comparison of the literature-derived electronic parameters with the observed ${ }^{31} \mathrm{P}$ NMR shifts of the phosphine oxides show a good correlation. With increasing electron deficiency $\chi$ increases, while $\delta$ decreases. It is important to note that the ${ }^{31} \mathrm{P}$ NMR shift of phosphine oxides is a reliable measure of the basicity as opposed to the ${ }^{31} \mathrm{P}$ NMR shift of phosphines, which is also influenced by sterics. ${ }^{39}$ As expected, the aryl phosphine oxides exhibit a weaker basicity than $\mathrm{OPBu}_{3}$. In comparison to $\mathrm{OPPh}_{3}$ the steric bulk is increased by the introduction of a methyl group in an ortho position in $\mathrm{OP}(\mathrm{o}-\mathrm{Tol})_{3}$. It should be noted that the steric influence is less than is indicated by the cone angle of the corresponding phosphine, because the distance between the metal center and the aryl groups is increased in comparison to that in the phosphine. In contrast, the introduction of a $\mathrm{CF}_{3}$ group in a para position in $\mathrm{OP}(p$ $\left.\mathrm{CF}_{3} \mathrm{C}_{6} \mathrm{H}_{4}\right)_{3}$ does not change the steric properties but increases electron deficiency. In $\mathrm{OP}\left(3,5-\left(\mathrm{CF}_{3}\right)_{2} \mathrm{C}_{6} \mathrm{H}_{3}\right)_{3}$ electron deficiency is further increased while the steric influence is believed to be similar to that of $\mathrm{OP}\left(p-\mathrm{CF}_{3} \mathrm{C}_{6} \mathrm{H}_{4}\right)_{3}\left(\theta=145^{\circ}\right.$ vs $\sim 151^{\circ}$ for $\left.\mathrm{P}\left(3,5-\mathrm{Me}_{2} \mathrm{C}_{6} \mathrm{H}_{3}\right)_{3}\right)^{40}$
The relative coordination strength of these phosphine oxides in comparison to that of dmso $\left(K_{\mathrm{OPR}_{3}}\right)$ was determined by ${ }^{1} \mathrm{H}$ NMR spectroscopy. The ${ }^{1} \mathrm{H}$ resonance of dmso in $\mathrm{CD}_{2} \mathrm{Cl}_{2}$ is shifted downfield from $2.54 \mathrm{ppm}$ (free dmso) to $2.95 \mathrm{ppm}$ by complexation to the $\mathrm{Pd}$ center of $\left(\mathrm{P}^{\wedge} \mathrm{O}\right) \mathrm{PdMe}(1) .^{41}$ Partial replacement by $\mathrm{OPR}_{3}$ leads to a high-field shift due to a fast equilibrium between Pd-bound and uncoordinated dmso. From the shift difference the ratio between 1-dmso and 1-L and consequently $K_{\mathrm{L}}$ at $25^{\circ} \mathrm{C}$ was calculated (cf. the Supporting Information). The results are summarized in Table 1 . Whereas

Table 1. $K_{\mathrm{L}}$ for 1 -dmso $+\mathrm{L} \leftrightarrows 1-\mathrm{L}+\mathrm{dmso}$

\begin{tabular}{|c|c|c|c|c|}
\hline entry & ligand & ant of $L$ (equir) & $\delta_{q}$ & $\mathrm{r}_{1}$ \\
\hline $1-1$ & $\mathrm{OPBu}_{3}$ & 1.0 & 2.68 & 3.5 \\
\hline $1-2$ & OPOct $_{3}$ & 1.2 & 2.66 & 3.3 \\
\hline $1-3$ & $\mathrm{OPPh}_{3}$ & 9.2 & 2.67 & 0.2 \\
\hline $1-4$ & $\mathrm{OP}(\mathrm{o}-\mathrm{Tol})_{3}$ & 11.3 & 2.78 & 0.03 \\
\hline $1-5$ & $\mathrm{OP}\left(p-\mathrm{CF}_{3} \mathrm{C}_{6} \mathrm{H}_{4}\right)_{3}$ & 10.2 & 2.77 & 0.04 \\
\hline $1-6$ & $\mathrm{OP}\left(3,5-\left(\mathrm{CF}_{3}\right)_{2} \mathrm{C}_{6} \mathrm{H}_{3}\right)_{3}$ & 9.2 & $2.91^{a t}$ & $\sim 0.001^{\circ}$ \\
\hline $1-7$ & $\mathrm{MeOH}$ & 9.4 & 2.82 & 0.02 \\
\hline $1-8$ & 2.6-lutidine & 1.4 & 2.54 & $\gg 10^{2}$ \\
\hline
\end{tabular}

${ }^{a} \Delta \delta$ is low due to the limited solubility of $\mathrm{OPR}_{3}$; consequently, the inaccuracy of $K_{\mathrm{L}}$ is enhanced.

both alkyl phosphine oxides coordinate slightly more strongly than dmso $\left(K_{\mathrm{OPBu}_{3}}=3.5, K_{\mathrm{OPOct}_{3}}=3.3\right)$, the more bulky and electron-deficient $\mathrm{OPPh}_{3}$ exhibits $K_{\mathrm{OPPh}_{3}}=0.2$ for the equilibrium 1-dmso $+\mathrm{OPR}_{3} \leftrightarrows 1-\mathrm{OPR}_{3}+$ dmso. An even weaker coordination is evident for the comparison with $\mathrm{OP}(0$ $\mathrm{Tol})_{3}\left(K_{\mathrm{OPTO}_{3}}=0.03\right)$ and $\mathrm{OP}\left(p-\mathrm{CF}_{3} \mathrm{C}_{6} \mathrm{H}_{4}\right)_{3}\left(K_{\mathrm{OP}\left(p-\mathrm{CF}_{3} \mathrm{Ar}_{2}\right)_{3}}=0.04\right.$, Table 1; compare $K_{\mathrm{L}}$ values for $\mathrm{MeOH}$ and 2,6-lutidine). Hence, the coordination strength can be controlled by either steric bulk or electron deficiency over a large range. The introduction of a second electron-withdrawing group in $\mathrm{OP}\left(3,5-\left(\mathrm{CF}_{3}\right)_{2} \mathrm{C}_{6} \mathrm{H}_{3}\right)_{3}$ further reduces the coordination strength significantly $\left(K_{\mathrm{OP}\left(3,5 \cdot \mathrm{CF}_{3} \mathrm{Ar}\right)_{3}} \approx 0.001\right)^{42}$

We note here that only minor changes of $K_{\mathrm{Opph}_{3}}$ in the temperature range from -25 to $25^{\circ} \mathrm{C}$ have been observed and that $\Delta H^{\circ}=8 \mathrm{~kJ} \mathrm{~mol}^{-1}$ and $\Delta S^{\circ}=13 \mathrm{~J} \mathrm{~mol}^{-1} \mathrm{~K}^{-1}$ have been determined by a van't Hoff analysis (cf. the Supporting Information). Extrapolation to typical polymerization conditions, i.e. $90^{\circ} \mathrm{C}$, results in $K_{\mathrm{Opph}_{3}}\left(90^{\circ} \mathrm{C}\right)=0.4$, which compares to $K_{\mathrm{Opph}_{3}}\left(25{ }^{\circ} \mathrm{C}\right)=0.2$. We assume that a similar small temperature dependence applies to all $K_{\mathrm{OpR}_{3}}$ values and that $K_{\mathrm{OPR}_{3}}<1$ should result in more active precatalysts 1-L: since during polymerization the monomer can also compete with $L$ for coordination to $\left(\mathrm{P}^{\wedge} \mathrm{O}\right) \mathrm{PdR}(\mathrm{R}=$ growing chain) according to the equilibrium $\left[\left(\mathrm{P}^{\wedge} \mathrm{O}\right) \mathrm{PdR}(\mathrm{L})\right]+$ ethylene $\leftrightarrows\left[\left(\mathrm{P}^{\wedge} \mathrm{O}\right) \mathrm{PdR}\right.$ (ethylene) $]+\mathrm{L}$, complexes $1-\mathrm{L}$ derived from phosphine oxides with a coordination strength weaker than that of dmso, i.e. from $\mathrm{OPPh}_{3}, \mathrm{OP}(0-\mathrm{Tol})_{3}, \mathrm{OP}\left(p-\mathrm{CF}_{3} \mathrm{C}_{6} \mathrm{H}_{4}\right)_{3}$ and $\mathrm{OP}\left(3,5-\left(\mathrm{CF}_{3}\right)_{2} \mathrm{C}_{6} \mathrm{H}_{3}\right)_{3}$, are expected to exhibit higher turnover frequencies than 1-dmso as long as saturation kinetics are not reached. Consequently, such complexes 1-L represent valuable synthetic targets for highly active single-component catalysts.

Complex Synthesis and Characterization, For the synthesis of phosphine oxide complexes $\mathbf{1}_{-\mathrm{OPR}_{3}}$ standard procedures were not applicable, since they are either based on introduction of the ligand with the Pd precursor, as with $\mathrm{L}=$ tmeda from $\left[(\right.$ tmeda $\left.) \mathrm{PdMe}_{2}\right],^{10,11,15,16}$ or subsequent ligand 
substitution by a more strongly coordinating ligand. ${ }^{5,10,12,14,19,43}$ Notably the more weakly coordinating dmso could be introduced by substitution of tmeda. This substitution occurs since tmeda is removed from the equilibrium $1 / 2(1)_{2}$-tmeda + dmso $\leftrightarrows 1$-dmso $+1 / 2$ tmeda under vacuum, due to the considerably higher volatility of tmeda vs dmso. ${ }^{13}$ However, an analogous procedure, e.g. solvent evaporation from a mixture of (1) ${ }_{2}$-tmeda and phosphine oxide in high-boiling solvents, did not result in the isolation of clean products. In an alternative approach, multinuclear "base-free" palladium alkyl complexes which are accessible, for example, by pyridine or lutidine abstraction with $\mathrm{B}\left(\mathrm{C}_{6} \mathrm{~F}_{5}\right)_{3}{ }^{12,18,19}$ may be suitable precursors for the preparation of phosphine oxide complexes $1-\mathbf{O P R}_{3}$. However, a more convenient synthesis starts from $[\{(1-\mathrm{Cl})$ $\left.\left.\mu-\mathrm{Na}_{2}\right)\right]^{44}$ Thus, chloride abstraction from easily accessible $\left.\left[\{(1-\mathrm{Cl})-\mu-\mathrm{Na}\}_{2}\right)\right]$ in the presence of phosphine oxides is expected to generate $1-\mathrm{OPR}_{3}$ if the presence of more strongly coordinating ligands is avoided (Scheme 1).

The viability of this general route was demonstrated by the synthesis and isolation of 1-dmso. As expected, also the

Scheme 1. Synthesis of 1-L

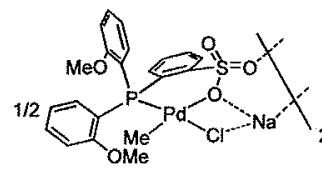

$\left[\left\{(1-\mathrm{Cl})-[-\mathrm{Na}\}_{2}\right]\right.$

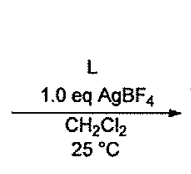

$25^{\circ} \mathrm{C}$ complexes 1-OPBu$u_{3}$ and 1-OPOct ${ }_{3}$ with the slightly more strongly coordinating alkyl phosphine oxides in comparison to dmso could be isolated. In contrast to more strongly coordinating ligands such as pyridine, the $\mathrm{Pd}-\mathrm{CH}_{3}$ group exhibits no visible ${ }^{3} J_{P H}$ coupling in the ${ }^{1} \mathrm{H}$ NMR spectrum at $25{ }^{\circ} \mathrm{C}$, as was also observed for 1-dmso. ${ }^{18}$ Coordination of the phosphine oxide in solution is further evidenced by a downfield shift of the $\mathrm{OPBu}_{3}$ signal in the ${ }^{31} \mathrm{P}$ NMR spectrum from 48 to 66 ppm. $^{45,46}$ In the solid state coordination of the phosphine oxide is evidenced by the shift of the $\nu(\mathrm{O}=\mathrm{P})$ band in the IR spectrum to lower frequencies from 1154 to $1113 \mathrm{~cm}^{-1}$ (Table 2). This observed frequency decrease can be related to a lowering of the $\mathrm{O}-\mathrm{P}$ bond order due to coordination. ${ }^{47}$ In addition, the

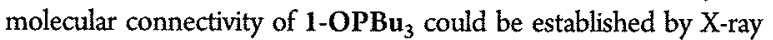
diffaction analysis (Figure 2). The analogous complex 1-OPOct exhibits very similar properties (cf. the Supporting Information). The synthesis of $1-\mathrm{OPPh}_{3}$ could also be achieved. Here, coordination is evidenced by a shift in the ${ }^{31} \mathrm{P}$ NMR from 27 to $35 \mathrm{ppm}$. A weaker coordination in solution by comparison to the trialkyl phosphine oxide complexes may be reflected in the much

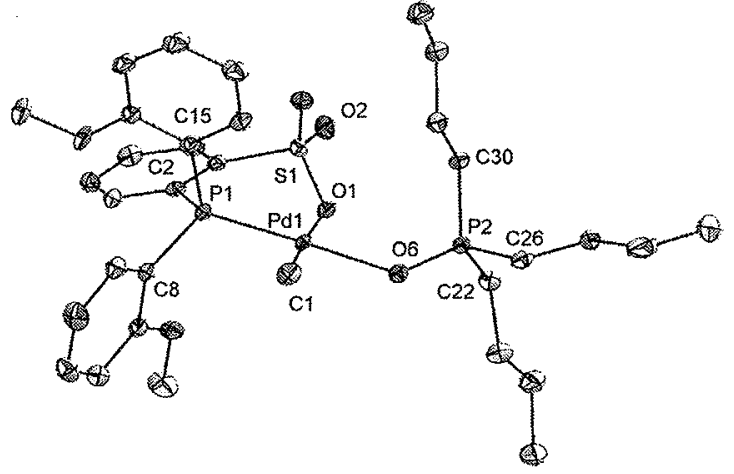

Figure 2. Molecular structure of $1-\mathrm{OPBu}_{3}$ with $50 \%$ probability ellipsoids. All hydrogen atoms are omitted for clarity. Selected bond lengths $(\AA)$ and angles (deg): $\operatorname{Pd}(1)-\mathrm{P}(1)=2.203(1) ; \operatorname{Pd}(1)-\mathrm{C}(1)=$ $2.010(3) ; \mathrm{Pd}(1)-\mathrm{O}(1)=2.157(2) ; \mathrm{Pd}(1)-\mathrm{O}(6)=2.129(2) ; \mathrm{O}(6)-$ $\mathrm{P}(2)=1.514(2) ; \mathrm{Pd}(1)-\mathrm{O}(6)-\mathrm{P}(2)=132.1(1) ; \mathrm{P}(1)-\mathrm{Pd}(1)-\mathrm{O}(6)=$ $174.4(1)$.

lower ${ }^{31} \mathrm{P}$ shift $\left(\triangle \delta=8 \mathrm{ppm}\right.$ for $\mathrm{OPPh}_{3}$ vs $18 \mathrm{ppm}$ for $\mathrm{OPBu}_{3}$ ) $\left.\mathrm{OPOCt}_{3}\right)$. In the IR spectrum again a decrease of the $\mathrm{P}=\mathrm{O}$ stretching frequency from 1189 to $1150 \mathrm{~cm}^{-1}$ is observed, which agrees with $\nu(\mathrm{O}=\mathrm{p}) 1145 \mathrm{~cm}^{-1}$ reported for the complex $\left[\mathrm{Pd}\left(\mathrm{NO}_{3}\right)_{2}\left(\mathrm{OPPh}_{3}\right)\left(\mathrm{PPh}_{3}\right)\right]_{.}^{46,48}$

Suitable crystals for $\mathrm{X}$-ray analysis were obtained from a $\mathrm{CHCl}_{3}$ solution. As for all reported $\left(\mathrm{P}^{\wedge} \mathrm{O}\right) \mathrm{PdMe}$ structures, the palladium complex adopts a square-planar geometry and the methyl group is situated in the position trans to the sulfonate group (Figure 3). Coordination of the phosphine oxide leads only to a small elongation of the $\mathrm{O}-\mathrm{P}$ bond $(1.503(3)$ vs $\sim 1.49 \AA^{49}$ in $\left.\mathrm{OPPh}_{3}\right)$, ${ }^{50}$ which is in accordance with the aforementioned bis(nitrato)-Pd(II) complex (vide supra; $\mathrm{O}-$ $\mathrm{P}=1.501(8) \AA)^{48}$ and $\mathrm{OPPh}_{3}$ complexes of other metals, for which in general a length change of $<1 \%$ is observed. ${ }^{45}$ In comparison to $1-\mathrm{OPBu}_{3}$ the $\mathrm{Pd}-\mathrm{OP}$ bond length is slightly elongated (2.138(3) $\AA$ for $1-\mathrm{OPPh}_{3}$ vs $2.129(2) \AA$ for 1 $\mathrm{OPBu}_{3}$; Figure 2), which is in agreement with the reduced coordination strength of $\mathrm{OPPh}_{3}$. Phosphine oxides are capable of showing a rather wide range of $\mathrm{M}-\mathrm{O}-\mathrm{P}$ bond angles $\left(\sim 180-140^{\circ}\right)$, while the bonding mode is discussed to be end-on, in contrast to the case for thio- and seleno-phosphorylic units, which show a side-on coordination $\left(\angle(\mathrm{M}-\mathrm{E}-\mathrm{P}) \approx 115-98^{\circ}\right) .^{45}$ In comparison the $\mathrm{M}-\mathrm{O}-\mathrm{P}$ bond angles for $\mathrm{Pd}$ complexes seem to be at the lower end of the scale, independent of the steric bulk at the $\mathrm{Pd}$ center created by additional ligands $\left(\angle(\mathrm{Pd}-\mathrm{O}-\mathrm{P})=133.5(1)^{\circ}\left(1-\mathrm{OPPh}_{3}\right), 132.1(1)^{\circ}\left(1-\mathrm{OPBu}_{3}\right)\right.$, $\left.132.1(4)^{\circ}\left[\mathrm{Pd}\left(\mathrm{NO}_{3}\right)_{2}\left(\mathrm{OPPh}_{3}\right)\left(\mathrm{PPh}_{3}\right)\right]\right)$. $^{48}$

Table 2. ${ }^{31} \mathrm{P}$ NMR Shift and $\mathrm{O}=\mathrm{P}$ IR Band of Pd-Coordinated vs Noncoordinated Phosphine Oxide OPR

\begin{tabular}{|c|c|c|c|c|c|c|c|}
\hline entry & R & $v(\mathrm{O}=\mathrm{P})_{\text {rood }}\left(\mathrm{cm}^{-1}\right)$ & $\nu(\mathrm{O}-\mathrm{P})_{\mathrm{re}}\left(\mathrm{cm}^{-1}\right)$ & $\Delta v(O-P)(\mathrm{cm})$ & $\delta^{3}(\mathrm{P})_{\text {oor }}(\mathrm{ppm})^{C}$ & $\delta\left(^{3} \mathrm{P}\right)_{\mathrm{rcc}}(\mathrm{ppm})$ & $\Delta \delta^{3}(\mathrm{p})(\mathrm{ppm})$ \\
\hline $2-1$ & $\mathrm{Bu}$ & 1113 & 1154 & 41 & 66 & 48 & 18 \\
\hline $2-2$ & Oct & 1107 & 1145 & 38 & 65 & 47 & 18 \\
\hline $2-3$ & $\mathrm{Ph}$ & 1150 & 1189 & 39 & 35 & 27 & 8 \\
\hline $2-4$ & $p-\mathrm{CF}_{3} \mathrm{C}_{6} \mathrm{H}_{4}$ & n.d. ${ }^{a}$ & 1198 & $b$ & 29 & 25 & 4 \\
\hline $2-5$ & $o-\mathrm{Tol}$ & n.d. ${ }^{a x}$ & 1185 & $b$ & 40 & 37 & 3 \\
\hline $2-6$ & $3,5-\left(\mathrm{CF}_{3}\right)_{2} \mathrm{C}_{6} \mathrm{H}_{3}$ & n.d. ${ }^{a}$ & 1216 & $b$ & $21^{d}$ & 21 & 0 \\
\hline
\end{tabular}

${ }^{a}$ Clear identification of the $\nu(\mathrm{O}=\mathrm{P})_{\text {coord }}$ band was not possible due to weak intensity and numerous overlapping bands. ${ }^{b} \mathrm{Disappearance}$ of the $\nu(\mathrm{O}=\mathrm{P})_{\text {free }}$ band is observable. ${ }^{c}$ From isolated raw material directly after dissolving in $\mathrm{CD}_{2} \mathrm{Cl}_{2^{*}}{ }^{d} \mathrm{No}$ clear homogeneous reaction mixture was obtained. 


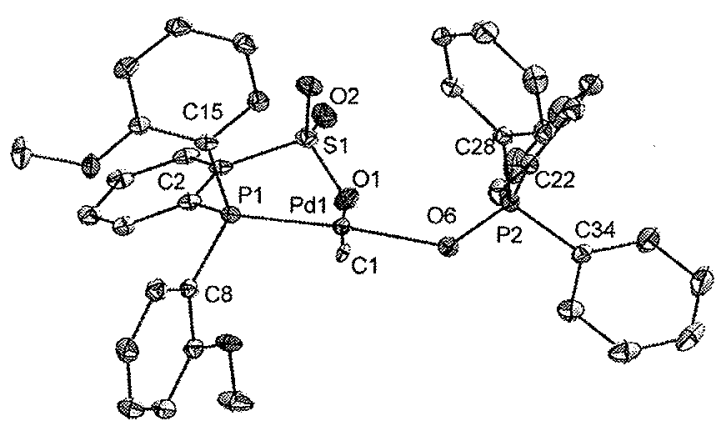

Figure 3. Molecular structure of 1-OPPh 3 with $50 \%$ probability ellipsoids. All hydrogen atoms and solvent molecules are omitted for clarity. Selected bond lengths $(\AA)$ and angles (deg): $\operatorname{Pd}(\mathrm{I})-\mathrm{P}(\mathrm{I})=$ $2.199(1) ; \mathrm{Pd}(1)-\mathrm{C}(1)=2.089(3) ; \mathrm{Pd}(1)-\mathrm{O}(1)=2.150(3) ; \mathrm{Pd}(1)-$ $\mathrm{O}(6)=2.138(3) ; \mathrm{O}(6)-\mathrm{P}(2)=1.503(3) ; \mathrm{Pd}(1)-\mathrm{O}(6)-\mathrm{P}(2)=$ $133.5(1) ; \mathrm{P}(1)-\mathrm{Pd}(1)-\mathrm{O}(6)=175.2(1)$.

Limitations for Coordinating Ligands Weaker than $O P P h_{3}$. The isolation of $1-\mathrm{OPPh}_{3}$ already revealed a relatively weak binding of this phosphine oxide to the Pd center, which affects the workup procedure: coordinated $\mathrm{OPPh}_{3}$ can be extracted from the complex by extensive washing with toluene, leading to partially insoluble material. In contrast, 1-OP(o$\mathrm{Tol})_{3}$ and 1-OP $\left(p-\mathrm{CF}_{3} \mathrm{C}_{6} \mathrm{H}_{4}\right)_{3}$, having phosphine oxides with a further decreased coordination strength (Table 1), were only obtained as crude products that are not stable in solution for a prolonged period of time. For the solid raw materials isolated by solvent evaporation after filtration a shift of the $\nu(\mathrm{PO})$ band in the IR spectra can be observed (Figure 4$),{ }^{51}$ evidencing a $\mathrm{Pd}-\mathrm{OPR}_{3}$ interaction. Dissolving the isolated material in $\mathrm{CH}_{2} \mathrm{Cl}_{2}$ yields a clear solution, and the ${ }^{31} \mathrm{P}$ NMR spectrum of the dissolved raw material shows a further reduced but significant shift for the $O \mathrm{OR}_{3}$ resonances $\left(\triangle \delta\left(\mathrm{OP}(\mathrm{o}-\mathrm{Tol})_{3}\right)=\right.$ $\left.3 \mathrm{ppm} ; \Delta \delta\left(\mathrm{OP}\left(p-\mathrm{CF}_{3} \mathrm{C}_{6} \mathrm{H}_{4}\right)_{3}\right)=4 \mathrm{ppm}\right)$. However, within $1-12 \mathrm{~h}$ in solution white precipitates form. Detailed analysis of these precipitates by ATR-IR and NMR spectroscopy in $\mathrm{CD}_{3} \mathrm{OD}$ confirmed the decomposition of 1-OP $(\boldsymbol{o}-\mathrm{Tol})_{3}$ and 1-OP $\left(p-\mathrm{CF}_{3} \mathrm{C}_{6} \mathrm{H}_{4}\right)_{3}$ to $\left[\left\{\left(\mathrm{P}^{\wedge} \mathrm{O}\right) \mathrm{PdMe}\right\}_{\mathrm{n}}\right]\left(\mathrm{1}_{\mathrm{n}}\right)$ (Scheme 2 and Figure 4; cf. Supporting Information). ${ }^{12,18,19,52,53}$

It is assumed that $1_{n}$ is bridged via coordination of multiple $\mathrm{Pd}$ centers to the sulfonate groups in analogy to $\left[\left\{\left(\mathrm{P}^{\wedge} \mathrm{O}\right)\right.\right.$.

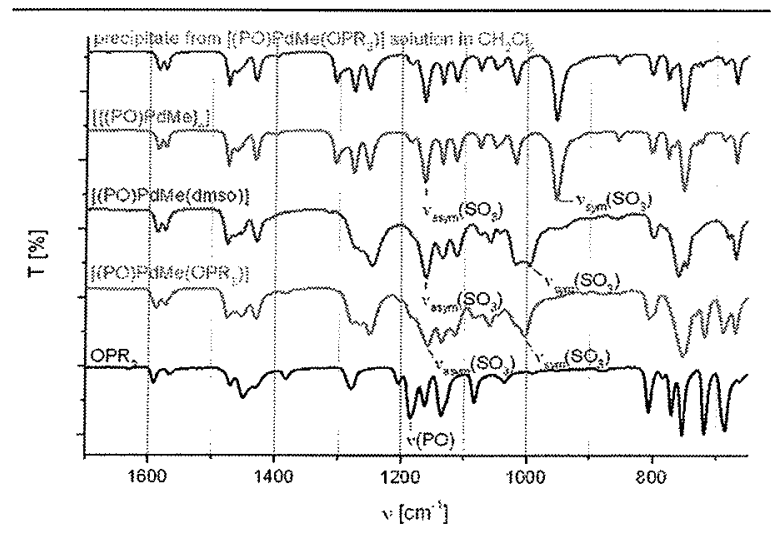

Figure 4. ATR-IR spectra of $\mathrm{OP}(0-\mathrm{Tol})_{3}$, ligated complexes $1-\mathrm{L}(\mathrm{L}=$ $\left.\mathrm{OP}(\mathrm{o}-\mathrm{Tol})_{3}, \mathrm{dmso}\right)$, the "base-free" complex $1_{n}$ and isolated precipitate from a $1-\mathrm{OP}(o-\mathrm{Tol})_{3}$ solution in $\mathrm{CH}_{2} \mathrm{Cl}_{2}$.
Scheme 2. Decomposition of 1-L

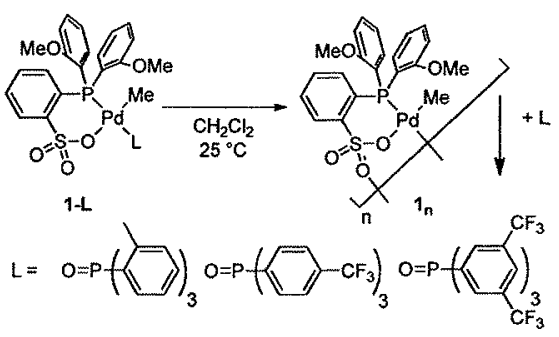

$\left.\left.\mathrm{PdCH}_{2} \mathrm{SiMe}_{3}\right\}_{2}\right] .^{12}$ An extensive IR comparison revealed a further detail. Removal of the coordinating ligand from 1-L and transformation to $\mathbf{1}_{\mathbf{n}}$ leads to the disappearance of a strong band at $\sim 1000 \mathrm{~cm}^{-1}$ assigned to $\nu_{\text {sym }}\left(\mathrm{SO}_{3}\right)$ and growth of a very strong band at $\sim 950 \mathrm{~cm}^{-1}$ (Figure 4, cf. Supporting Information). Such a frequency shift could be induced after coordination of the $\mathrm{SO}_{3}$ group to a further palladium center: e.g, in $1_{n^{*}}$ In this context it is important to note that for all other (ligand coordinated) $\left(\mathrm{P}^{\wedge} \mathrm{O}\right) \mathrm{PdMe}$ complexes $1-\mathrm{L}$ described in this work the $\nu_{\text {sym }}\left(\mathrm{SO}_{3}\right)$ band can always be found at around $1000 \mathrm{~cm}^{-1}$ (Figure 4), which is in agreement with literature data for Pd-coordinated benzenesulfonic acid. ${ }^{54}$ Hence the absence of a strong band around $950 \mathrm{~cm}^{-1}$ in the IR spectra can be seen as a reliable indication for the formation of the discrete ligand-coordinated $\left(\mathrm{P}^{\wedge} \mathrm{O}\right) \mathrm{PdMe}$ species 1-L. Decomposition of 1-OP $(o-\mathrm{Tol})_{3}$ and $1-\mathrm{OP}\left(p-\mathrm{CF}_{3} \mathrm{C}_{6} \mathrm{H}_{4}\right)_{3}$ to free phosphine oxide and $1_{n}$ can be monitored by ${ }^{1} \mathrm{H}$ NMR spectroscopy over the course of several hours, as $\mathbf{1}_{n}$ precipitates upon formation, which results in diminishing signals for 1-OP $(o-\mathrm{Tol})_{3}$ and 1-OP $\left(p-\mathrm{CF}_{3} \mathrm{C}_{6} \mathrm{H}_{4}\right)_{3}$, whereas $\mathrm{OPR}_{3}$ remains in solution (Figure $S$ ).

In the case of the significantly more weakly coordinating $\mathrm{OP}\left(3,5-\left(\mathrm{CF}_{3}\right)_{2} \mathrm{C}_{6} \mathrm{H}_{3}\right)_{3}$, crude 1-OP $\left(3,5-\left(\mathrm{CF}_{3}\right)_{2} \mathrm{C}_{6} \mathrm{H}_{3}\right)_{3}$ already

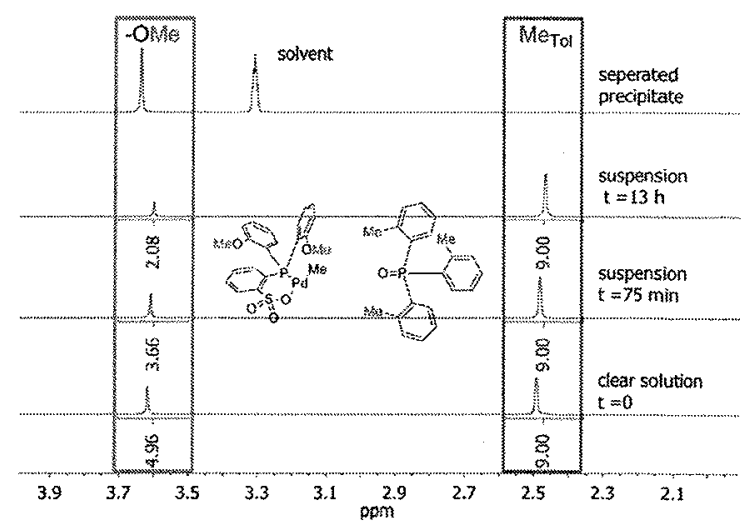

Figure 5. 'H NMR spectra (expansion, $400 \mathrm{MHz}, \mathrm{CD}_{2} \mathrm{Cl}_{2}$ ) of the decomposition of 1-OP(o-Tol $)_{3}$ with time and ${ }^{1} \mathrm{H}$ NMR spectrum (400 $\mathrm{MHz}, \mathrm{MeOD})$ of the resulting precipitate. ${ }^{55}$

contains substantial amounts of $\mathbf{I}_{\mathrm{n}}$ as evidenced by the IR spectrum, the limited solubility, and the intensity ratio of anisyl methoxy to aromatic $3,5-\left(\mathrm{CF}_{3}\right)_{2} \mathrm{C}_{6} \mathrm{H}_{3}{ }^{\mathrm{I}} \mathrm{H}$ resonances (cf. Supporting Information). The instability of 1-OP(o-Tol $)_{3}$ and 1-OP $\left(p-\mathrm{CF}_{3} \mathrm{C}_{6} \mathrm{H}_{4}\right)_{3}$ and their decomposition toward $\mathrm{I}_{\mathrm{n}}$ and free phosphine oxide as well as the elusive isolation of $1-\mathrm{OP}\left(3,5-\left(\mathrm{CF}_{3}\right)_{2} \mathrm{C}_{6} \mathrm{H}_{3}\right)_{3}$ clearly point to a coordination 


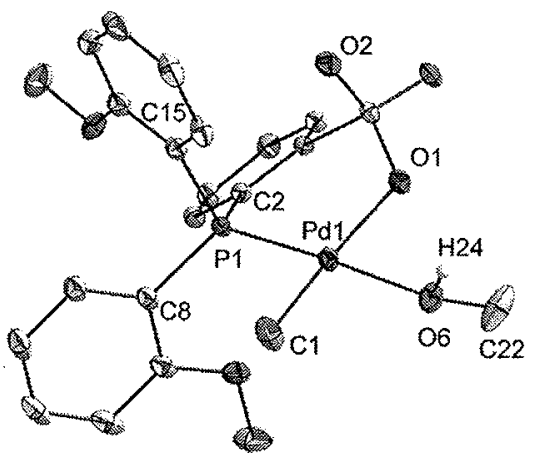

Figure 6. Molecular structure of $\mathrm{I}-\mathrm{MeOH}$ with $50 \%$ probability ellipsoids. All solvent molecules and hydrogen atoms, except the hydroxyl hydrogen $\mathrm{H} 24$, are omitted for clarity. Selected bond lengths $(\AA)$ and angles (deg): $\operatorname{Pd}(1)-P(1)=2.200(1) ; \operatorname{Pd}(1)-C(1)=$ $2.032(2) ; \mathrm{Pd}(1)-\mathrm{O}(1)=2.158(1) ; \mathrm{Pd}(1)-\mathrm{O}(6)=2.139(2) ; \mathrm{O}(6)-$ $\mathrm{C}(22)=1.429(3) ; \mathrm{Pd}(1)-\mathrm{O}(6)-\mathrm{C}(22)=118.2(1) ; \mathrm{P}(1)-\mathrm{Pd}(1)-$ $O(6)=176.9(0)$.

strength of palladium-coordinated sulfonate which effectively competes with these phosphine oxides.

However, kinetic control may allow for the isolation of complexes of weakly coordinating ligands such as methanol. While methanol binds less strongly to $\left(\mathrm{P}^{\wedge} \mathrm{O}\right) \mathrm{PdMe}$ than do $\mathrm{OP}(o-\mathrm{Tol})_{3}$ or $\mathrm{OP}\left(p-\mathrm{CF}_{3} \mathrm{C}_{6} \mathrm{H}_{4}\right)_{3}$ (Table 1, entries 1-4 and 1-5 vs 1-7), 1- $\mathrm{MeOH}$ was isolated by crystallization from methanol solution and analyzed by X-ray diffraction analysis (Figure 6). However, even solid 1-MeOH in the absence of a methanol atmosphere loses methanol within $20 \mathrm{~min}$ at room temperature and forms $1_{n}$ as evidenced by ATR-IR spectroscopy (cf. Supporting Information).

NMR Studies of the Influence of Coordinating Ligand $L$ on Monomer Insertion. To study the influence of the coordinating ligand on monomer insertion in detail, the insertions of ethylene and methyl acrylate were investigated by NMR spectroscopy.

The insertion of ethylene into the $\mathrm{Pd}-\mathrm{Me}$ bond of 1-OPPh and of species 1 generated by in situ chloride abstraction from $\left.\left[\{(1-\mathrm{Cl})-\mu-\mathrm{Na}\}_{2}\right)\right]$ with $\mathrm{AgBF}_{4}$ in the absence of additional ligands was monitored at $-15^{\circ} \mathrm{C}$ (likely, in 1 the $\left[\left(\mathrm{P}^{\wedge} \mathrm{O}\right)\right.$ $\mathrm{PdMe}$ fragment is weakly coordinated by the methylene chloride solvent) ${ }^{56}$ The determined first-order rate constants (22 equiv of ethylene as compared to palladium) show that at $-15^{\circ} \mathrm{C} 1$ is consumed slightly more quickly than $1-\mathrm{OPPh}_{3}$ $\left(k_{1-\text { opph }_{3} \text { ethylene }}=5.7 \times 10^{-4} \mathrm{~s}^{-1}, k_{1, \text { ethylene }}=7.0 \times 10^{-4} \mathrm{~s}^{-1}\right.$; cf. Supporting Information). A similar trend with increasing coordination strength was also observed for the reaction of $\left[\left(\mathrm{P}^{\wedge} \mathrm{O}\right) \mathrm{PdMe}(\mathrm{L})\right]$ and 1 with MA. Rate constants for the first insertion ${ }^{\text {Ist }} k_{1-\mathrm{L}}$ range from $0.6 \times 10^{-3} \mathrm{~s}^{-1}$ for $1-\mathrm{OPBu}_{3}$ to $3.2 \times$ $10^{-3} \mathrm{~s}^{-1}$ for 1 at $0.02 \mathrm{~mol} \mathrm{~L}^{-1}$ palladium and $0.3 \mathrm{~mol} \mathrm{~L}^{-1} \mathrm{MA}$ (Figure 7). Insertion of $\mathrm{MA}$ at $25^{\circ} \mathrm{C}$ into $\left[\left(\mathrm{P}^{\wedge} \mathrm{O}\right) \mathrm{PdCH}(\mathrm{C}\right.$. (O) OMe) $\left.\mathrm{CH}_{2} \mathrm{Me}\right]$ also proceeds the fastest for 1 ( ${ }^{\text {second }} k_{1}=$ $\left.9.2 \times 10^{-5} \mathrm{~s}^{-1}\right)$ as compared to $1-\mathrm{OPBu}_{3}\left({ }^{\text {second }} \mathbf{k}_{1-\mathrm{OPBu}}=8.2 \times\right.$ $10^{-6} \mathrm{~s}^{-1}$ ) (Figure 8).

Since the rate constants for the second MA insertion are significantly affected by the applied ligands, it can be concluded that the coordination strength of dmso, $\mathrm{OPPh}_{3}$, and $\mathrm{OPBu}_{3}$ exceeds that of the carbonyl group in the possible four-membered chelate $\kappa^{2}-\mathrm{C}, \mathrm{O}-\left[\left(\mathrm{P}^{\wedge} \mathrm{O}\right) \mathrm{PdCH}(\mathrm{C}(\mathrm{O}) \mathrm{OMe})\right.$. $\left.\mathrm{CH}_{2} \mathrm{Me}\right]$. This is in accordance with the isolation of the

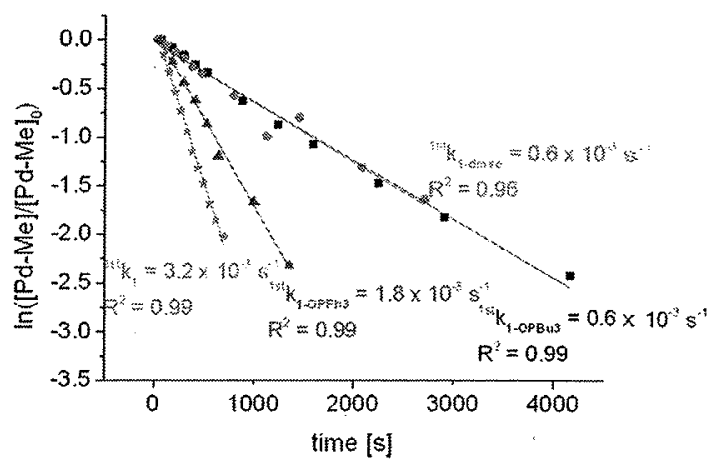

Figure 7. First-order consumption of $\mathrm{Pd}-\mathrm{Me}$ by insertion of MA $\left([\mathrm{Pd}]=0.02 \mathrm{~mol} \mathrm{~L}^{-1}\right.$ in $\mathrm{CD}_{2} \mathrm{Cl}_{2} 25^{\circ} \mathrm{C}$ ).

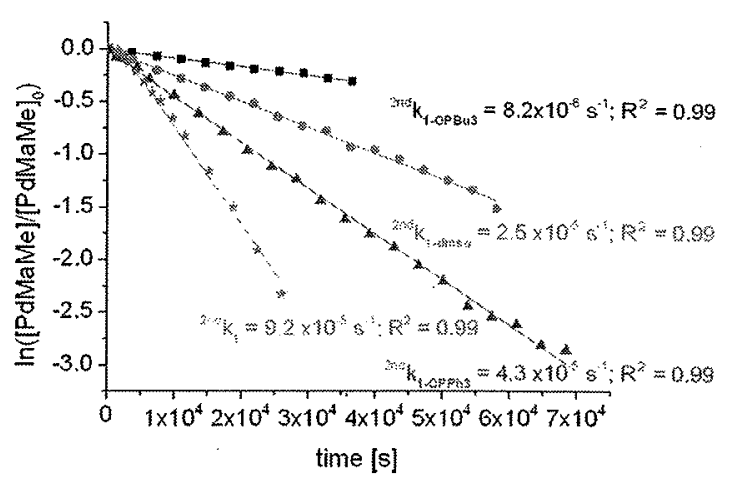

Figure 8. First-order consumption of $\mathrm{Pd}-\mathrm{CH}\left(\mathrm{C}(\mathrm{O}) \mathrm{OMe}^{-} \mathrm{CH}_{2}-\mathrm{Me}\right.$ by consecutive insertion of $\mathrm{MA}\left([\mathrm{Pd}]=0.02 \mathrm{~mol} \mathrm{~L}^{-1}\right.$ in $\left.\mathrm{CD}_{2} \mathrm{Cl}_{2}, 25^{\circ} \mathrm{C}\right)$.

dmso-coordinated insertion product $\kappa^{2}-\mathrm{C}, \mathrm{O}-\left[\left(\mathrm{P}^{\wedge} \mathrm{O}\right) \mathrm{PdCH}(\mathrm{C}\right.$. (O) OMe $) \mathrm{CH}_{2} \mathrm{Me}$ (dmso)]. . $^{13}$

Influence of Ligand L on Polymerization Activities. Replacement of pyridine or 2,6-lutidine by the significantly more weakly coordinating dmso in catalyst precursors $1-\mathrm{L}$ has resulted in a nearly 10-fold activity increase in ethylene homopolymerizations at a pressure of 5 bar. At this low ethylene pressure the equilibrium $\left[\left(\mathrm{P}^{\wedge} \mathrm{O}\right) \mathrm{PdR}(\mathrm{L})\right]+$ ethylene $\leftrightarrows$ $\left[\left(\mathrm{P}^{\wedge} \mathrm{O}\right) \mathrm{PdR}\right.$ (ethylene $\left.)\right]+\mathrm{L}(\mathrm{R}=$ growing chain $)$ is believed to be shifted far to the ethylene complex for $\mathrm{L}=$ dmso, while pyridine or 2,6-lutidine compete much more effectively with ethylene and require higher [ethylene] in order to reach saturation kinetic conditions. Arguably, the most promising species to reach saturation kinetic behavior at the lowest possible [ethylene] is the "base-free" catalyst precursor $\left(\mathrm{P}^{\wedge} \mathrm{O}\right) \mathrm{PdMe}(1)$. However, the formation of $1_{\mathrm{n}}$ from 1 (e.g., after pyridine abstraction from 1-pyridine) and the low solubility of $1_{n}$ have so far prevented catalytic activities higher than those observed for 1-dmso. ${ }^{18}$ Therefore, $1-\mathrm{OPR}_{3}(\mathrm{R}=\mathrm{Ph}$, $o$-Tol, $p-\mathrm{CF}_{3} \mathrm{C}_{6} \mathrm{H}_{4}$ ) species described in this work are of interest for achieving saturation kinetic conditions at the lowest possible [ethylene]. To this end, polymerizations at variable ethylene concentrations with the isolable defined precatalysts 1-dmso, 1-OPBu$u_{3}$, and 1-OPPh $\mathrm{Ph}_{3}$ were studied. In addition, the polymerization of ethylene in the presence of 1 prepared by in situ chloride abstraction from $\left.1 / 2\left[\{(1-\mathrm{Cl})-\mu-\mathrm{Na}\}_{2}\right)\right]$ with 1 equiv of $\mathrm{AgBF}_{4}$ was investigated. Note that, in this context, $\left.\left[((1-\mathrm{Cl})-\mu-\mathrm{Na}\}_{2}\right)\right]$ contains up to 1 equiv of a coordinating solvent such as acetone or diethyl ether per $\mathrm{Na}$ depending on the preparative workup. 
Polymerization results (Figure 9) show that in situ generated 1 as well as $\mathbf{1 - O P P h}, \mathbf{1 - O P B u}$, and 1-dmso exhibit essentially similar activities at a given ethylene pressure $(2,3.5,5$, and $10 \mathrm{bar}$, $90^{\circ} \mathrm{C}$ ). As far as slight differences beyond experimental error are

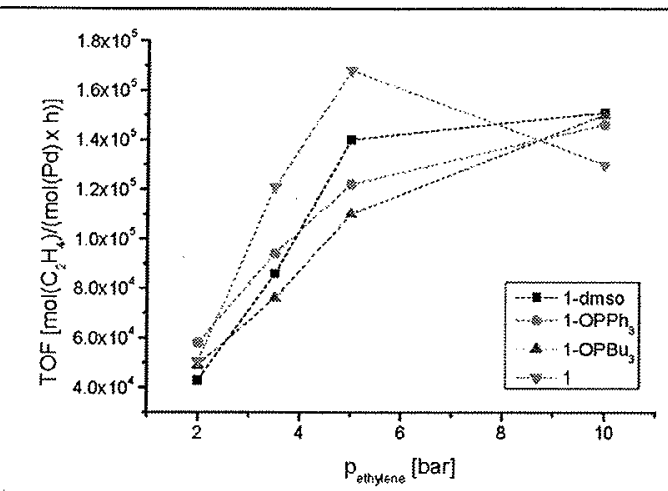

Figure 9. Dependence of average activity in ethylene homopolymerization on pressure for 1 and 1-L $\left(\mathrm{L}=\right.$ dmso, $\left.\mathrm{OPBu}_{3}, \mathrm{OPPh}_{3}\right)$. Reaction conditions: $t=30 \mathrm{~min} ; T=90{ }^{\circ} \mathrm{C} ; V$ (toluene $)=100 \mathrm{~mL}$; $[\mathrm{Pd}]=40 \mu \mathrm{mol} \mathrm{L}^{-1}$. Dashed lines are merely a guide to the eye.

observed, these tend to reflect the coordination strength of the ligand $\mathrm{L}$ or the absence of $\left.\mathrm{L}\left(\left[\{(\mathbf{1}-\mathrm{Cl})-\mu-\mathrm{Na}\}_{2}\right)\right] / \mathrm{AgBF}_{4}\right)$.

These findings qualitatively agree with previous studies of the effect of dmso on ethylene polymerization activities with 1-dmso, which showed that the equilibrium $\left[\left(\mathrm{P}^{\wedge} \mathrm{O}\right) \mathrm{PdR}-\right.$ (ethylene $)]+$ dmso $\leftrightarrows\left[\left(\mathrm{P}^{\wedge} \mathrm{O}\right) \mathrm{PdR}(\mathrm{dmso})\right]+$ ethylene $(\mathrm{R}=$ growing chain) does render a portion of the metal centers inactive by coordination of the 1 equiv of dmso introduced with the catalyst precursor. However, the ethylene complex is strongly favored in this equilibrium already at low ethylene pressure, such that the inactive portion is rather small, and saturation kinetic conditions are met. ${ }^{18}$

As outlined, the equilibria $\left[\left(\mathrm{P}^{\wedge} \mathrm{O}\right) \mathrm{PdR}(\mathrm{L})\right]+$ monomer $\leftrightarrows$ $\left[\left(\mathrm{P}^{\wedge} \mathrm{O}\right) \mathrm{R}\right.$ (monomer) $]+\mathrm{L}$ are relevant in polymerization studies (activation of catalyst precursors, reversible deactivation of active species) as well as NMR investigations of insertion rates (preequilibria to insertion). It is worth noting that the effect of the coordination strength of $L$ will be much more pronounced in NMR studies $\left([\mathrm{Pd}] \approx 10^{-2} \mathrm{~mol} \mathrm{~L}^{-1}\right)$ vs polymerization studies $\left([\mathrm{Pd}] \approx 10^{-4}-10^{-6} \mathrm{~mol} \mathrm{~L}^{-1}\right)$, as here concentrations of metal species and consequently of free $\mathrm{L}$ liberated from the metal precursor are typically much higher, while monomer concentrations are usually roughly similar.

While all the above experimental observations fit into this conclusive picture, they also suggest that the strong dependence of average polymerization rates in the regime of up to 5 bar of ethylene pressure (Figure 9) is not simply related to competitive relative binding of monomer vs $L$ (or sulfonate). For the low-pressure polymerizations at $2,3.5$, and 5 bar of ethylene a pronounced drop in catalytic activity over time is observed by mass-flow monitoring. Thus, at 2 bar the ethylene uptake into the reactor decreases to $65-40 \%$ of its initial value after $30 \mathrm{~min}$ polymerization time. At 5 bar the decrease of ethylene uptake is not as pronounced but still drops to $80-70 \%$ of the initial values (cf. Supporting Information). Possibly, a dependence of catalyst stability on ethylene concentration affects the polymerization behavior.

The choice of catalyst precursor, i.e. $\left[\{(1-\mathrm{Cl})-\mu-\mathrm{Na}\}_{2}\right]$ plus $\mathrm{AgBF}_{4}, 1-\mathrm{OPBu}_{3}, 1-\mathrm{OPPh}_{3}$, or 1-dmso, has a measurable influence on the activity also in ethylene-MA copolymerizations at low [ethylene], which correlates to the presence and the nature of the coordinating ligand and its equilibrium constant $K_{\mathrm{L}}$ vs dmso: at 3.5 bar of ethylene and $0.5 \mathrm{~mol} \mathrm{~L} \mathrm{~L}^{-1}$ MA in situ generated 1 produces $50 \%$ more copolymer than I-OPBu${ }_{3}$, while the copolymer composition remains essentially identical (Table 3 entries $3-1$ vs 3-4). The increase in activity is steady in the order $1-\mathrm{OPBu}_{3}<1$-dmso $<1-\mathrm{OPPh}_{3}<1$, which reflects the coordination strengths of the present $\mathrm{OPR}_{3}$ and dmso ligands (vide supra, Table 1). Also note that with decreasing coordination strength a slight increase in molecular weight is evident (Table 3). This increase in molecular weight is tentatively explained by a ligand-induced opening of the sixmembered chelates $\left[\left(\mathrm{P}^{\wedge} \mathrm{O}\right) \mathrm{PdCH}(\mathrm{R}) \mathrm{CH}_{2} \mathrm{CH}(\mathrm{C}(\mathrm{O}) \mathrm{OMe})\right.$ -

Table 3. Ethylene-Methyl Acrylate Copolymerization ${ }^{a}$

\begin{tabular}{|c|c|c|c|c|c|c|c|}
\hline entry & precursor & $\begin{array}{c}\text { yeld } \\
(\mathrm{g})\end{array}$ & $(\%)^{\circ}$ & $\mathrm{COF}_{2}$ & TOF & $M_{r}$ & $M_{n}$ \\
\hline $3-1$ & 1-OPBu & 0.8 & 14.2 & 1927 & 319 & 2.0 & 1.7 \\
\hline $3-2$ & 1-dmso & 0.9 & 14.8 & 2047 & 356 & 2.3 & 1.7 \\
\hline $3-3$ & $1-\mathrm{OPPh}_{3}$ & 1.0 & 13.7 & 2404 & 380 & 2.5 & 1.8 \\
\hline 3-4 & 1 (in & 1.2 & 13.2 & 2888 & 439 & 2.6 & 1.8 \\
\hline
\end{tabular}

${ }^{a}$ Reaction conditions: total volume of toluene $+\mathrm{MA}, 50 \mathrm{~mL} ;[\mathrm{MA}]=$ $0.5 \mathrm{~mol} \mathrm{~L} \mathrm{~L}^{-1} ; 3.5$ bar ethylene pressure; $93{ }^{\circ} \mathrm{C} ; 20 \mu \mathrm{mol} \mathrm{Pd}(\mathrm{II}) ; 1 \mathrm{~h}$ reaction time. ${ }^{b}$ Determined by ${ }^{1} \mathrm{H}$ NMR in $\mathrm{CDCl}_{3} .{ }^{c} \mathrm{In}$ units of $(\mathrm{mol}$ of $\left.\mathrm{C}_{2} \mathrm{H}_{4}\right)(\mathrm{mol} \text { of } \mathrm{Pd})^{-1} \mathrm{~h}^{-1}$. In units of ( $\mathrm{mol}$ of MA) (mol of Pd) ${ }^{-1}$ $\mathrm{h}^{-1}$. In units of $10^{3} \mathrm{~g} \mathrm{~mol}^{-1}$, determined by ${ }^{1} \mathrm{H}$ NMR. ${ }^{f}$ Determined by GPC.

$\left.\mathrm{CH}_{2} \mathrm{R}^{\prime}\right]$ and concomitant $\beta$-H elimination, whereas opening by the monomer leads to the following insertion.

While the increase in activity is limited, in situ generated 1 , i.e. $\left[\left\{(1-\mathrm{Cl})-\mu-\mathrm{Na}_{2}\right]\right.$ plus $\mathrm{AgBF}_{4}$, proves to be the most active catalyst for ethylene-MA copolymerizations. This is quite remarkable, since from a synthetic point of view $[\{(1-\mathrm{Cl})-\mu$ $\left.\mathrm{Na}\}_{2}\right]$ is easily available in a one-step reaction from $\mathrm{Na}\left(\mathrm{P}^{\wedge} \mathrm{O}\right)$ and [(cod) $\mathrm{PdMeCl}]$ without further time-consuming transformations.

While rate constants for the MA insertion from NMR studies vary by factors of 5-10 (Figures 7 and 8 ), the polymer yields only vary by a factor of 1.5 (Table 3 ). In addition to the aforementioned effect of different concentrations in NMR studies vs polymerization experiments, the stability of sixmembered chelates $\mathbf{C}$ formed in copolymerization by coordination of a penultimate incorporated MA-derived repeating unit can contribute to reducing the effect of other ligands $L$ on activity at a given amount of catalyst precursor added per reaction volume (Scheme 3). ${ }^{18}$ Equilibration of these chelates with incoming olefin is strongly shifted to $\mathrm{C}$ as compared to the olefin-coordinated species $D$. Even if olefin insertion from species $\mathbf{A}$ and $\mathbf{B}$ were sensitive to the coordination strength of $\mathbf{L}$ due to the equilibration according to $K_{\mathrm{A}}$ and $K_{\mathrm{B}}$, the following rate-determining insertion from $\mathrm{D}$ is mainly affected by $K_{\mathrm{C} 2}$ and thus is mostly insensitive to $\mathrm{L}$, as long as $\mathrm{L}$ is not significantly more strongly coordinating than the $\kappa$-O carbonyl oxygen in $\mathrm{C}$. As noted previously, olefin insertion from $D$ represents a bottleneck in the MA-ethylene copolymerization which is intrinsically linked to the coordination strength of the carbonyl oxygen in $\mathrm{C}^{57}$ 
Scheme 3. Rate-Determining Equilibria in the Copolymerization of Ethylene with MA

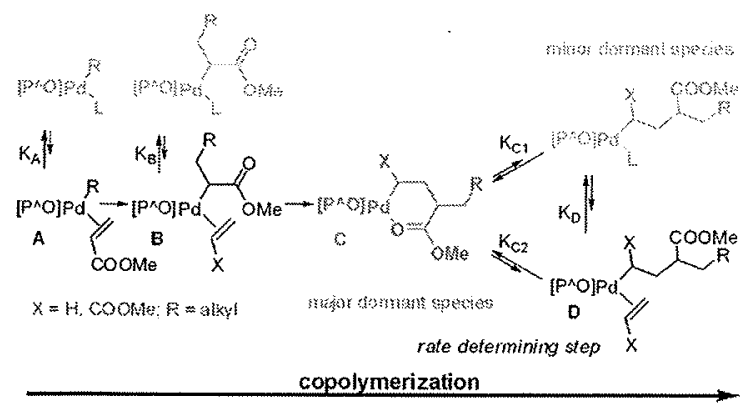

SUMMARY AND CONCLUSION

Phosphine oxides are easily available monodentate ligands with a defined coordination site and allow wide manipulation of coordination strength due to manifold possible steric and electronic modifications. Determination of the coordination strength $K_{\mathrm{L}}$ toward the $\mathrm{Pd}$ center of $\left(\mathrm{P}^{\wedge} \mathrm{O}\right) \mathrm{PdMe}$ for several phosphine oxides $\mathrm{OPR}_{3}$ in comparison to dmso by ${ }^{1} \mathrm{H}$ NMR spectroscopy revealed that the coordination strength decreases with increasing steric bulk and electron deficiency. The investigated $\mathrm{OPR}_{3}$ ligands cover a range of $K_{\mathrm{L}}$ from $\sim 3$ to 0.001 vs dmso, decreasing in the order $\mathrm{R}=\mathrm{Bu} \approx \mathrm{Oct}>\mathrm{Ph}>$ $o$ Tol $\approx p-\mathrm{CF}_{3}-\mathrm{C}_{6} \mathrm{H}_{4}>3,5-\left(\mathrm{CF}_{3}\right)_{2} \mathrm{C}_{6} \mathrm{H}_{3}$. Preparative synthesis afforded the new complexes 1-OPBu $3,1-\mathrm{OPOct}_{3}$, and $\mathbf{1}-\mathrm{OPPh}_{3}$, as shown by complete characterization by NMR and IR spectroscopy, mass spectrometry, and elemental analysis. In addition, X-ray diffraction analysis of $1-\mathrm{OPBu}_{3}$ and $1-\mathrm{OPPh}_{3}$ confirm the $\kappa$-O coordination of the phosphine oxides to palladium. So far, 1-OPPh 3 with $K_{\mathrm{OPPh}_{3}}=0.2$ is the most weakly coordinated stable $\left(\mathrm{P}^{\wedge} \mathrm{O}\right) \mathrm{PdMe}$ complex synthesized. Studies with weaker coordinating ligands disclosed that for $\left[\left(\mathrm{P}^{\wedge} \mathrm{O}\right) \mathrm{PdMe}(\mathrm{L})\right]$ the minimum of coordination strength for $\mathrm{L}$ is limited, due to the ability of the $\left(\mathrm{P}^{\wedge} \mathrm{O}\right) \mathrm{PdMe}$ fragment to form ill-defined multinuclear palladium complexes $\mathbf{I}_{\mathrm{n}}$. More weakly coordinating ligands still can temporally stabilize the $\left(\mathrm{P}^{\wedge} \mathrm{O}\right) \mathrm{PdMe}$ fragment, but ultimately $1_{\mathrm{n}}$ forms, as evidenced by NMR and IR spectroscopic studies.

Detailed insertion studies by NMR techniques showed that 1 exhibits the highest rate constants for ethylene insertion and for the first and second MA insertions.

Homo- and copolymerization studies revealed that the most active catalyst, 1 , is available by in situ chloride abstraction from $\left[\{(1-\mathrm{Cl})-\mu-\mathrm{Na}\}_{2}\right]$. So far, 1 generated by in situ chloride abstraction from $\left[\{(1-\mathrm{Cl})-\mu-\mathrm{Na}\}_{2}\right]$ represents the best model substance for a species free of significantly coordinating monodentate ligand $\mathrm{L}$ with the highest possible activity in ethylene-MA copolymerizations.

\section{EXPERIMENTAL DETAILS}

Unless noted otherwise, all manipulations of air-sensitive compounds were carried out under an inert atmosphere using standard glovebox or Schlenk techniques. THF, toluene, $\mathrm{CH}_{2} \mathrm{Cl}_{2}$ and $\mathrm{MeOH}$ were dried using standard protocols. ${ }^{58}$ Pentane and $\mathrm{Et}_{2} \mathrm{O}$ were dried by passing through columns equipped with aluminum oxide/molecular sieves $3 \AA$. Ethylene ( 3.5 grade) supplied by Praxair and methyl acrylate (99\%) supplied by Aldrich were used as received. [(tmeda)PdMe $\left.{ }_{2}\right]^{59}$ [(cod) $\mathrm{PdMeCl}],{ }_{2}^{6}$-[ bis(2-methoxyphenyl)phosphino]benzenesulfonic acid, ${ }^{11} 1$-dmso, ${ }^{13}$ and $\left[\{(1-\mathrm{Cl})-\mu \text {-Na }\}_{2}\right]^{44}$ were prepared by known procedures. NMR spectra were recorded on a Varian Unity INOVA
400, a Bruker Avance DRX 600, or a Bruker Avance III 600 spectrometer, equipped with a cryoprobe head. ${ }^{1} \mathrm{H}$ and ${ }^{13} \mathrm{C}$ NMR chemical shifts were referenced to the solvent signal. ${ }^{19} \mathrm{~F}$ and ${ }^{31} \mathrm{P}$ NMR chemical shifts were referenced to $\mathrm{CFCl}_{3}$ and $85 \% \mathrm{H}_{3} \mathrm{PO}_{4}$, respectively. Multiplicities are given as follows (or combinations thereof): $s$, singlet, $\mathrm{d}$, doublet, $\mathrm{t}$, triplet, $v t$, virtual triplet, $m$, multiplet. The identity and purity of metal complexes was established by ${ }^{1} \mathrm{H},{ }^{13} \mathrm{C}$, and ${ }^{31} \mathrm{P}$ NMR and elemental analysis. NMR assignments were confirmed by ${ }^{1} \mathrm{H},{ }^{1} \mathrm{H}$ gCOSY, ${ }^{1} \mathrm{H},{ }^{13} \mathrm{C}$ gHSQC, and ${ }^{1} \mathrm{H}_{1}{ }^{13} \mathrm{C}$ gHMBC experiments. For copolymers molecular weights were determined by ${ }^{1} \mathrm{H}$ NMR and polydispersity indexes were determined by GPC on a Polymer Laboratories PL-GPC 50 instrument with two PLgel $5 \mu \mathrm{m}$ MLXED-C columns and an RI detector in THF against a polystyrene standard. Elemental analysis and FAB mass spectra were obtained by the Analytical Services at the Department of Chemistry, University of Konstanz. Elemental analyses were performed on an Elementar Vario MICRO cube instrument. FAB mass spectra were obtained with a double-focusing Finnagan MAT 8200 mass spectrometer equipped with a Ion Tech (Teddington, U.K) FAB ion source. ESI mass spectra were recorded on a Bruker Esquire 3000+ instrument.

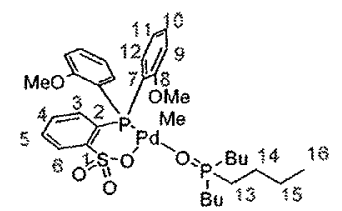

$\left[\left(\mathrm{P}^{\wedge} \mathrm{O}\right) \mathrm{PdMe}\left(\mathrm{OPBu}_{3}\right)\right]\left(1-\mathrm{OPBu}_{3} ; \mathrm{P}^{\wedge} \mathrm{O}=\kappa^{2}-\mathrm{P}, \mathrm{O}-2-\left(2-\mathrm{MeOC}_{6} \mathrm{H}_{4}\right)_{2}\right.$ $\left.\mathrm{PC}_{6} \mathrm{H}_{4} \mathrm{SO}_{3}\right)$ ). A suspension of $99 \mathrm{mg}(0.08 \mathrm{mmol}, 0.5$ equiv) of [ $\{(1-\mathrm{Cl})$ $\left.\mu-\mathrm{Na}\}_{2}\right], 33 \mathrm{mg}\left(0.17 \mathrm{mmol}, 1.1\right.$ equiv) of $\mathrm{AgBF}_{4}$, and $35 \mathrm{mg}(0.16 \mathrm{mmol}$, 1.0 equiv) of $\mathrm{OPBu}_{3}$ in $5 \mathrm{~mL}$ of $\mathrm{CH}_{2} \mathrm{Cl}_{2}$ was stirred for $30 \mathrm{~min}$ in the dark. The resulting precipitate was filtered off to afford a yellow solution. The filtrate was evaporated and the resulting residue was washed with pentane and dried under vacuum to yield $1-\mathrm{OPBu}_{3}$ as a beige solid (100 mg, $0.14 \mathrm{mmol}, 88 \%$ ). Crystals suitable for X-ray diffraction analysis were obtained from a saturated toluene solution at $-20{ }^{\circ} \mathrm{C}$

${ }^{1} \mathrm{H}$ NMR $\left(400 \mathrm{MHz}, \mathrm{CD}_{2} \mathrm{Cl}_{2}\right): \delta 8.02\left(\mathrm{dd},{ }^{3} \mathrm{H}_{\mathrm{HH}}=7.1,{ }^{4} J_{\mathrm{PH}}=4.9\right.$, $1 \mathrm{H}, 6-\mathrm{H}), 7.66(\mathrm{br}, 2 \mathrm{H}, 12-\mathrm{H}), 7.52(\mathrm{vt}, J=7.8,2 \mathrm{H}, 10-\mathrm{H}), 7.43(\mathrm{vt}$ $J=7.4,1 \mathrm{H}, 5-\mathrm{H}), 7.32-7.25(\mathrm{~m}, 2 \mathrm{H}, 4-\mathrm{H}$ and $3-\mathrm{H}), 7.01(\mathrm{vt}, J=7.4$, $2 \mathrm{H}, 11-\mathrm{H}), 6.93\left(\mathrm{dd},{ }^{3} \mathrm{~J}_{\mathrm{HH}}=7.8,{ }^{4} J_{\mathrm{PH}}=4.8,2 \mathrm{H}, 9-\mathrm{H}\right), 3.60(\mathrm{~s}, 6 \mathrm{H}, \mathrm{Ar}-$ $\left.\mathrm{OCH}_{3}\right), 1.95-1.85(\mathrm{~m}, 6 \mathrm{H}, 13-\mathrm{H}), 1.66-1.58(\mathrm{~m}, 6 \mathrm{H}, 14-\mathrm{H}), 1.51-$ $1.43(\mathrm{~m}, 6 \mathrm{H}, 15-\mathrm{H}), 0.94\left(\mathrm{t},{ }^{3} \mathrm{HH}_{\mathrm{H}}=7.3,9 \mathrm{H}, 16-\mathrm{H}\right), 0.14(\mathrm{~s}, 3 \mathrm{H}, \mathrm{Pd}$ $\left.\mathrm{CH}_{3}\right) \cdot{ }^{31} \mathrm{P}\left\{{ }^{1} \mathrm{H}\right\}$ NMR $\left(162 \mathrm{MHz}, \mathrm{CD}_{2} \mathrm{Cl}_{2}\right): \delta 66.4\left(\mathrm{br}, \mathrm{OPBu}_{3}\right), 27.2$ $\left(\mathrm{P}_{\mathrm{Ar}}\right) .{ }^{13} \mathrm{C}\left\{{ }^{\mathrm{I}} \mathrm{H}\right\} \mathrm{NMR}\left(101 \mathrm{MHz}, \mathrm{CD}_{2} \mathrm{Cl}_{2}\right): \delta 160.9\left(\mathrm{~d},{ }^{2} \mathrm{P}_{\mathrm{PC}}=1.4, \mathrm{C} 8\right)$ $148.9\left(\mathrm{~d},{ }^{2} J_{\mathrm{PC}}=15.7, \mathrm{Cl}\right), 138.4(\mathrm{br}, \mathrm{Cl} 2), 135.0\left(\mathrm{~d},{ }^{2} J_{\mathrm{PC}}=2.5, \mathrm{C} 3\right)$, $133.7(\mathrm{C} 10), 130.5(\mathrm{CS}), 128.6\left(\mathrm{br} \mathrm{d},{ }^{3} J_{\mathrm{PC}}=6.0, \mathrm{C} 4\right), 128.1\left(\mathrm{~d},{ }^{1} J_{\mathrm{PC}}=\right.$ $52.9, \mathrm{C} 2), 127.9\left(\mathrm{~d},{ }^{3} J_{\mathrm{PC}}=8.0, \mathrm{C} 6\right), 120.8\left(\mathrm{~d},{ }^{3} J_{\mathrm{PC}}=12.4, \mathrm{C} 11\right), 117.1$ $\left(\mathrm{d},{ }^{1} J_{\mathrm{PC}}=59.4, \mathrm{C} 7\right), 111.9\left(\mathrm{~d},{ }^{3} \mathrm{JC}_{\mathrm{PC}}=4.5, \mathrm{C} 9\right), 55.7\left(\mathrm{Ar}-\mathrm{OCH}_{3}\right), 27.5$ (d, $\left.{ }^{1}{ }_{\mathrm{PC}}=64.8, \mathrm{C} 13\right), 24.7\left(\mathrm{~d},{ }^{3} J_{\mathrm{PC}}=14.7, \mathrm{C} 15\right), 24.3\left(\mathrm{~d},{ }^{2} J_{\mathrm{PC}}=3.8\right.$ C14), $14.0\left(\mathrm{Cl}\right.$ ), 0.9 (br, $\left.\mathrm{Pd}-\mathrm{CH}_{3}\right)$. Anal. Calcd for $\mathrm{C}_{33} \mathrm{H}_{48} \mathrm{O}_{6} \mathrm{P}_{2} \mathrm{PdS}$ : C, $53.48 ; \mathrm{H}, 6.53$. Found: C, 53.53; H, 6.53. MS (FAB): $m / z 740$ $[\mathrm{M}]^{+}, 725[\mathrm{M}-\mathrm{Me}]^{+}, 522\left[\mathrm{M}-\mathrm{OPBu}_{3}\right]^{+}, 507\left[\mathrm{M}-\mathrm{OPBu}_{3}-\right.$ $\mathrm{Me}^{+}, 216\left[\mathrm{OPBu}_{3}+\mathrm{H}\right]^{+}$. ATR-IR: $1 / \lambda\left(\mathrm{cm}^{-1}\right) 2956(\mathrm{~m}), 2869(\mathrm{~m})$

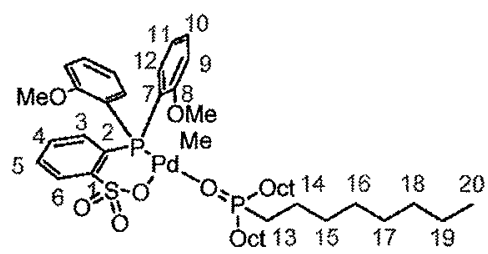

$1588(\mathrm{~m}), 1575(\mathrm{~m}), 1476(\mathrm{~m}), 1427(\mathrm{~m}), 1248(\mathrm{~s}), 1159(\mathrm{~s}$ $\left.\nu_{\text {asym }}\left(\mathrm{SO}_{3}\right)\right), 1113(\mathrm{ss}, \nu(\mathrm{P}=\mathrm{O})), 988\left(\mathrm{~s}, \nu_{\mathrm{sym}}\left(\mathrm{SO}_{3}\right)\right), 747(\mathrm{~s}), 669(\mathrm{~m})$.

$\left[\left(\mathrm{P}^{\wedge} \mathrm{O}\right) \mathrm{PdMe}\left(\mathrm{OPOCt}_{3}\right)\right] \quad\left(1-\mathrm{OPOCt}_{3} ; \mathrm{P}^{\wedge} \mathrm{O}=\kappa^{2}-\mathrm{P}, \mathrm{O}-2-(2-\right.$

$\left.\left.\mathrm{MeOC}_{6} \mathrm{H}_{4}\right)_{2} \mathrm{PC}_{6} \mathrm{H}_{4} \mathrm{SO}_{3}\right)$ ). A suspension of $92 \mathrm{mg}(0.08 \mathrm{mmol}, 0.5$ equiv) 
of $\left[((\mathrm{I}-\mathrm{Cl})-\mu-\mathrm{Na}\}_{2}\right], 32 \mathrm{mg}(0.16 \mathrm{mmol}, 1.0$ equiv $)$ of $\mathrm{AgBF}_{41}$ and $64 \mathrm{mg}\left(0.16 \mathrm{mmol}, 1.0\right.$ equiv) of $\mathrm{OPOct}_{3}$ in $5 \mathrm{~mL}$ of $\mathrm{CH}_{2} \mathrm{Cl}_{2}$ was stirred for $30 \mathrm{~min}$ in the dark. The resulting precipitate was filtered off to afford a yellow solution. The filtrate was evaporated and the resulting residue was washed with pentane and dried under vacuum to yield 1-OPOct ${ }_{3}$ as a beige solid (122 $\left.\mathrm{mg}, 0.13 \mathrm{mmol}, 81 \%\right)$.

${ }^{1} \mathrm{H}$ NMR $\left(400 \mathrm{MHz}, \mathrm{CD}_{2} \mathrm{Cl}_{2}\right): \delta 8.03\left(\mathrm{dd},{ }^{3} \mathrm{~J}_{\mathrm{HH}}=7.6,{ }^{4} J_{\mathrm{PH}}=4.7\right.$, $1 \mathrm{H}, 6-\mathrm{H}), 7.67(\mathrm{br}, 2 \mathrm{H}, 12-\mathrm{H}), 7.51(\mathrm{vt}, J=7.8,2 \mathrm{H}, 10-\mathrm{H}), 7.42(\mathrm{vt}$ $J=7.2,1 \mathrm{H}, 5-\mathrm{H}), 7.35-7.21(\mathrm{~m}, 2 \mathrm{H}, 4 . \mathrm{H}$ and $3-\mathrm{H}), 7.01(\mathrm{vt}, J=7.5$ $2 \mathrm{H}, 11-\mathrm{H}), 6.93\left(\mathrm{dd},{ }^{3} \mathrm{H}_{\mathrm{HH}}=8.2,{ }^{4} \mathrm{~J}_{\mathrm{PH}}=4.7,2 \mathrm{H}, 9-\mathrm{H}\right), 3.60(\mathrm{~s}, 6 \mathrm{H}, \mathrm{Ar}-$ $\left.\mathrm{OCH}_{3}\right), 1.96-1.84(\mathrm{~m}, 6 \mathrm{H}, 13-\mathrm{H}), 1.69-1.56(\mathrm{~m}, 6 \mathrm{H}, 14 \mathrm{H}), 1.49-1.40$ $(\mathrm{m}, 6 \mathrm{H}, 15-\mathrm{H}), 1.38-1.21(\mathrm{~m}, 24 \mathrm{H}, 16-\mathrm{H}$ and $17-\mathrm{H} \& 18-\mathrm{H}$ and $19-\mathrm{H})$, $0.88\left(\mathrm{t},{ }^{3} \mathrm{JHH}_{\mathrm{HH}}=6.7,9 \mathrm{H}, 20-\mathrm{H}\right), 0.14\left(\mathrm{~s}, 3 \mathrm{H}, \mathrm{Pd}-\mathrm{CH}_{3}\right) .{ }^{31} \mathrm{P}\left\{{ }^{1} \mathrm{H}\right\} \mathrm{NMR}$ $\left(162 \mathrm{MHz}, \mathrm{CD}_{2} \mathrm{Cl}_{3}\right): \delta 65.3\left(\mathrm{br}, \mathrm{OPOCt}_{3}\right), 26.1\left(\mathrm{P}_{\mathrm{A}}\right) \cdot{ }^{13} \mathrm{C}\left\{{ }^{1} \mathrm{H}\right\}$ NMR $\left(101 \mathrm{MHz}, \mathrm{CD}_{2} \mathrm{Cl}_{2}\right): \delta 160.9\left(\mathrm{~d},{ }^{2}{ }_{\mathrm{IPC}}=1.7, \mathrm{C} 8\right), 149.2(\mathrm{br}, \mathrm{Cl}), 138.4$ $(\mathrm{br}, \mathrm{C} 12), 135.0\left(\mathrm{~d},{ }^{2} \mathrm{I}_{\mathrm{PC}}=2.7, \mathrm{C} 3\right), 133.6(\mathrm{C} 10), 130.5(\mathrm{C} 5), 128.5(\mathrm{br}$ d, $\left.{ }^{3} J_{\mathrm{PC}}=8.5, \mathrm{C} 4\right), 128.2\left(\mathrm{~d},{ }^{1} \mathrm{~J}_{\mathrm{PC}}=52.8, \mathrm{C} 2\right), 128.0\left(\mathrm{~d},{ }^{3} J_{\mathrm{PC}}=8.9, \mathrm{C} 6\right)$, $120.8\left(\mathrm{~d},{ }^{3} \mathrm{~J}_{\mathrm{PC}}=12.5, \mathrm{C} 11\right), 117.2\left(\mathrm{~d}, \mathrm{~J}_{\mathrm{PC}}=59.7, \mathrm{C} 7\right), 111.9\left(\mathrm{~d},{ }^{3} J_{\mathrm{PC}}=\right.$ 4.6, C9), 55.7 ( $\left.\mathrm{Ar}-\mathrm{OCH}_{3}\right), 32.4(\mathrm{C} 18), 31.7\left(\mathrm{~d},{ }^{3} \mathrm{lp}=14.3, \mathrm{Cl} 15\right), 29.7$ $(\mathrm{C} 16 \& \mathrm{C} 17), 27.8\left(\mathrm{~d},{ }^{1} \mathrm{~J}_{\mathrm{PC}}=64.5, \mathrm{Cl} 3\right), 23.2(\mathrm{C} 19), 22.3\left(\mathrm{~d},{ }^{2} J_{\mathrm{PC}}=3.8\right.$, C14), 14.4 (C20), 0.9 (br, Pd- $\mathrm{CH}_{3}$ ). Anal. Calcd for $\mathrm{C}_{45} \mathrm{H}_{72} \mathrm{O}_{6} \mathrm{P}_{2} \mathrm{PdS}$ : C, 59.43; H, 7.98. Found: C, 58.18; H, 7.87. MS (FAB): $m / z 908\left[\mathrm{M}^{+}, 893\right.$ $[\mathrm{M}-\mathrm{Me}]^{+}, 773\left[\mathrm{H}\left(\mathrm{OPOct}_{3}\right)_{2}\right]^{+}, 522\left[\mathrm{M}-\mathrm{OPOct}_{3}\right]^{+}, 507[\mathrm{M}-$ OPOct $_{3}-\mathrm{Me}^{+}, 387\left[\mathrm{OPOct}_{3}+\mathrm{H}\right]^{+}$. ATR-IR: $\mathrm{I} / \lambda\left(\mathrm{cm}^{-1}\right) 2923(\mathrm{~m})$, $2853(\mathrm{~m}), 1588(\mathrm{w}), 1574(\mathrm{w}), 1476(\mathrm{~m}), 1464(\mathrm{~m}), 1430(\mathrm{~m}), 1262(\mathrm{~s})$, $1251(\mathrm{~s}), 1159\left(\mathrm{~s}, \nu_{\text {asym }}\left(\mathrm{SO}_{3}\right)\right), 1107(\mathrm{ss}, \nu(\mathrm{P}=\mathrm{O})), 1001\left(\mathrm{~s}, \nu_{\mathrm{sym}}\left(\mathrm{SO}_{3}\right)\right)$, $755(\mathrm{~s}), 669(\mathrm{~m})$.

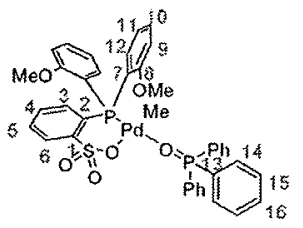

$\left[\left(\mathrm{P}^{\wedge} \mathrm{O}\right) \mathrm{PdMe}\left(\mathrm{OPPh}_{3}\right)\right]\left(1-\mathrm{OPPh}_{3 ;} ; \mathrm{P}^{\wedge} \mathrm{O}=\kappa^{2}-\mathrm{P}, \mathrm{O}-2-\left(2-\mathrm{MeOC}_{6} \mathrm{H}_{4}\right)_{2}-\right.$ $\left.\mathrm{PC}_{6} \mathrm{H}_{4} \mathrm{SO}_{3}\right)$ ). A suspension of $131 \mathrm{mg}(0.10 \mathrm{mmol}, 0.5$ equiv) of [ $\{(1-\mathrm{Cl})$ $\left.\mu-\mathrm{Na}_{2}\right], 57 \mathrm{mg}\left(0.20 \mathrm{mmol}, 1.0\right.$ equiv) of $\mathrm{OPPh}_{3}$, and $40 \mathrm{mg}$ ( $0.21 \mathrm{mmol}, 1.0$ equiv) of $\mathrm{AgBF}_{4}$ in $20 \mathrm{~mL}$ of $\mathrm{CH}_{2} \mathrm{Cl}_{2}$ was stirred for $12 \mathrm{~h}$ in the dark. The resulting precipitate was filtered off to give a yellow solution. The filtrate was evaporated and the resulting residue was suspended in $20 \mathrm{~mL}$ of pentane and stirred for $3 \mathrm{~h}$. The precipitate was collected by filtration and dried under vacuum to yield 1-OPPh as a slightly yellow solid ( $125 \mathrm{mg}, 0.16 \mathrm{mmol}, 80 \%)$. Crystals suitable for X-ray diffraction analysis were obtained from a $\mathrm{CHCl}_{3}$ solution after layering with pentane.

${ }^{1} \mathrm{H}$ NMR $\left(600 \mathrm{MHz}, \mathrm{CD}_{2} \mathrm{Cl}_{2}\right): \delta 8.04-8.00(\mathrm{~m}, 1 \mathrm{H}, 6 \cdot \mathrm{H}), 7.82-$ $7.75(\mathrm{~m}, 6 \mathrm{H}, 14-\mathrm{H}), 7.63-7.48(\mathrm{~m}, 13 \mathrm{H}, 10-\mathrm{H}$ and $12-\mathrm{H} \& 15-\mathrm{H}$ and $16-\mathrm{H}), 7.44-7.40(\mathrm{~m}, 1 \mathrm{H}, \mathrm{S}-\mathrm{H}), 7.31-7.24(\mathrm{~m}, 2 \mathrm{H}, 3-\mathrm{H}$ and $4-\mathrm{H})$, $6.98(\mathrm{vt}, J=7.2,2 \mathrm{H}, \mathrm{I} 1-\mathrm{H}), 6.92\left(\mathrm{dd},{ }^{3} J_{\mathrm{HH}}=7.5,{ }^{4} \mathrm{JH}_{\mathrm{PH}}=4.7,2 \mathrm{H}, 9-\mathrm{H}\right)$,

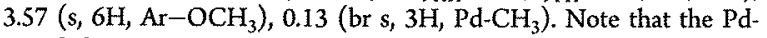
Me shift is very sensitive to small amounts of impurities, e.g. $\mathrm{H}_{2} \mathrm{O}$. ${ }^{31} \mathrm{P}\left\{{ }^{1} \mathrm{H}\right\}$ NMR $\left(162 \mathrm{MHz}, \mathrm{CD}_{2} \mathrm{Cl}_{2}\right): \delta 34.9\left(\mathrm{br}, \mathrm{OPPh}_{3}\right), 27.0\left(\mathrm{P}_{\mathrm{Ar}}\right)$. ${ }^{13} \mathrm{C}\left\{{ }^{1} \mathrm{H}\right\}$ NMR (151 MHz, $\left.\mathrm{CD}_{2} \mathrm{Cl}_{2}\right): \delta 160.9(\mathrm{C} 8), 148.9(\mathrm{br}, \mathrm{C} 1)$, $138.4(\mathrm{br}, \mathrm{C} 12), 135.0(\mathrm{C} 3), 133.7(\mathrm{C} 10), 133.0\left(\mathrm{~d},{ }^{2}{ }_{\mathrm{PC}}=10.2, \mathrm{C} 14\right)$, $132.9(\mathrm{C} 16), 131.8\left(\mathrm{~d},{ }^{1} J_{\mathrm{PC}}=110.9, \mathrm{C} 13\right), 130.5(\mathrm{C} 5), 129.1(\mathrm{~d}$, $\left.{ }^{3} \mathrm{JP}_{\mathrm{CP}}=12.6, \mathrm{C} 15\right), 128.7(\mathrm{br}, \mathrm{C} 4), 128.1(\mathrm{br}, \mathrm{C} 6), 128.0\left(\mathrm{~d},{ }^{1} J_{\mathrm{CP}}=53.7\right.$, C2), $120.9\left(\mathrm{~d},{ }^{3} \mathrm{I}_{\mathrm{PC}}=12.3, \mathrm{C} 11\right), 117.0\left(\mathrm{~d},{ }^{1} \mathrm{JPC}_{\mathrm{PC}}=59.3, \mathrm{C} 7\right), 111.9$ $\left(\mathrm{d},{ }^{3} \mathrm{JC}_{\mathrm{PC}}=4.3, \mathrm{Cg}\right), 55.7\left(\mathrm{Ar}-\mathrm{OCH}_{3}\right), 1.1\left(\mathrm{br}, \mathrm{Pd}^{-} \mathrm{CH}_{3}\right)$. Anal. Calcd for $\mathrm{C}_{39} \mathrm{H}_{36} \mathrm{O}_{6} \mathrm{P} 2 \mathrm{PdS}: \mathrm{C}, 58.47 ; \mathrm{H}, 4.53$. Found: $\mathrm{C}, 58.47 ; \mathrm{H}_{4}$ 4.81. MS (FAB): $m / z 802[\mathrm{M}]^{+}, 785[\mathrm{M}-\mathrm{Me}]^{+}, 522\left[\mathrm{M}-\mathrm{OPPh}_{3}\right]^{+}, 507$ $\left[\mathrm{M}-\mathrm{OPPh}_{3}-\mathrm{Me}\right]^{+}, 278\left[\mathrm{OPPh}_{3}+\mathrm{H}\right]^{+}$. ATR-IR: $1 / \lambda\left(\mathrm{cm}^{-1}\right) 3062$ $(\mathrm{w}), 1587(\mathrm{~m}), 1574(\mathrm{~m}), 1476(\mathrm{~m}), 1434(\mathrm{~m}), 1253(\mathrm{~s}), 1162$ $\left(\mathrm{s}, \nu_{\text {asym }}\left(\mathrm{SO}_{3}\right)\right), 1150(\mathrm{~s}, \nu(\mathrm{P}=\mathrm{O})), 1115(\mathrm{~s}), 998\left(\mathrm{~s}, \nu_{\mathrm{sym}}\left(\mathrm{SO}_{3}\right)\right), 755$ $(s), 723$ (ss), $694(s), 670(s)$.

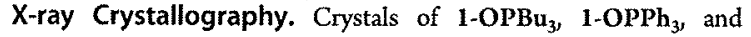
1- $\mathrm{MeOH}$ were grown as described in the corresponding experimental section. X-ray diffraction analyses were performed at $100 \mathrm{~K}$ on a STOE IPDS-II diffractometer equipped with a graphite-monochromated radiation source (Mo $\mathrm{K} \alpha, \lambda=0.71073 \AA$ ) and an image plate detection system. The structures were solved by Patterson and direct methods (SHELXS-97), ${ }^{62}$ completed with difference Fourier syntheses, and refined with full-matrix least squares using SHELXL$97^{63}$ minimizing $w\left(F_{o}{ }^{2}-F_{c}{ }^{2}\right)^{2}$.

\section{AUTHOR INFORMATION}

\section{Corresponding Author}

*E-mail: stefan.mecking@uni-konstanz.de.

\section{Notes}

The authors declare no competing financial interest.

\section{ACKNOWLEDGMENTS}

B.N. acknowledges support by the state of Baden-Württemberg by a Landesgraduiertenförderung-Stipend. This work is financially supported by the DFG (Me 1388/10). S.M. is indebted to the Fonds der Chemischen Industrie. We thank D. Guironnet for providing crystals of 1-MeOH.

\section{REFERENCES}

(1) Mülhaupt, R Macromol. Chem. Phys. 2003, 204, 289-327.

(2) Drent, E.; Dijk, R. v.; Ginkel, R. v.; Oort, B. v.; Pugh, R I. Chem. Commun. 2002, 744-745.

(3) (a) Nakamura, A.; Ito, S.; Nozaki, K Chem. Rev. 2009, 109, 5215-5244. (b) Chen, E. Y. X. Chem. Rev. 2009, 109, 5157-5214 (c) Takeuchi, D. Dalton Trans. 2010, 39,311-328. (d) Camacho, D. H.; Guan, Z. Chem. Commun. 2010, 46, 7879-7893. (e) Berkefeld, A.; Mecking, S. Angew. Chem., Int. Ed. 2008, 47, 2538-2542.

(4) For some very recent $\left(\mathrm{P}^{\wedge} \mathrm{O}\right) \mathrm{Pd}$ catalyst developments and their influence on polymerization behavior see: (a) Gott, A. L.; Piers, W. E.; Dutton, J. L.; McDonald, R; Parvez, M. Organometallics 2011, 30 4236-4249. (b) Kim, Y.; Jordan, R. F. Organometallics 2011, 30, 4250-4256. (c) Wucher, P.; Caporaso, L.; Roesle, P.; Ragone, F.j Cavallo, L.; Mecking, S.; Göttker-Schnetmann, I. Proc. Natl. Acad. Sci. U.S.A. 2011, 108, 8955-8959. (d) Zhou, X.; Jordan, R. F Organometallics 2011, 30, 4632-4642. (e) Chen, C.; Anselment, T. M. J.; Fröhlich, R; Rieger, B.; Kehr, G.; Erker, G. Organometallics 2011, 30, 5248-5257. (f) Anselment, T. M. J.; Wichmann, C. Anderson, C. E.; Herdtweck, E.; Rieger, B. Organometallics 2011, 30 6602-6611. (g) Anselment, T. M. J.; Anderson, C. E; Rieger, B.; Boeddinghaus, M. B.; Fassler, T. F. Dalton Trans. 2011, 40, 83048313. (h) Piche, L.; Daigle, J-C.; Poli, R; Claverie, J. P. Eur. J. Inorg. Chem. 2010, 4595-4601. (i) Nagai, Y.; Kochi, T.; Nozaki, K. Organometallics $2009,28,6131-6134$.

(5) Kochi, T.; Noda, S.; Yoshimura, K.; Nozaki, K. J. Am. Chem. Soc. 2007, 129, 8948-8949.

(6) Nozaki, K; Kusumoto, S.; Noda, S.; Kochi, T.; Chung, L. W. Morokuma, K. J. Am. Chem. Soc. 2010, 132, 16030-16042.

(7) Ito, S.; Munakata, K; Nakamura, A; Nozaki, K. J. Am. Chem. Soc. 2009, 131, 14606-14607.

(8) Rünzi, T.; Fröhlich, D.; Mecking, S. J. Am. Chem. Soc. 2010, 132, 17690-17691.

(9) In this context note that recently the inhibition of ethylene polymerization with 1 -dmso by addition of saturated compounds with various polar groups has been studied: Friedberger, T; Wucher, P.; Mecking, S. J. Am. Chem. Soc. 2012, 134, 1010-1018. 
(10) Allen, N. T.; Goodall, B. L.; McIntosh, L. H. Eur. Patent Appl. EP1760086A2, 2007.

(11) Skupov, K. M.; Marella, P. R; Simard, M.; Yap, G. P. A; Allen, N.; Conner, D.; Goodall, B. L.; Claverie, J. P. Macromol. Rapid Commun. 2007, 28, 2033-2038.

(12) Vela, J.; Lief, G. R; Shen, Z.; Jordan, R. F. Organometallics 2007 26, 6624-6635.

(13) Guironnet, D.; Roesle, P.; Rünzi, T.; Göttker-Schnetmann, I.; Mecking, S. J. Am. Chem. Soc. 2009, 131, 422-423.

(14) Zhang, D.; Guironnet, D.; Göttker-Schnetmann, I.; Mecking, S. Organometallics 2009, 28, 4072-4078.

(15) Hearley, A. K.; Nowack, R J.; Rieger, B. Organometallics 2005, 24, 2755-2763.

(16) Liu, S.; Borkar, S.; Newsham, D.; Yennawar, H.; Sen, A. Organometallics 2007, 26, 210-216.

(17) Related stoichiometric studies of acrylate insertion in $\mathrm{Pd}(\mathrm{II})$ complexes: (a) Braunstein, P.; Frison, C.; Morise, X. Angew. Chem., Int. Ed. 2000, 39, 2867-9870. (b) Braunstein, P.j Agostinho, M. Chem. Commun. 2007, 58-60.

(18) Guironnet, D.; Caporaso, L.; Neuwald, B.; Göttker-Schnetmann, I.; Cavallo, L.; Mecking, S. J. Am. Chem. Soc. 2010, 132, 4418-4426.

(19) Luo, S.; Vela, J.; Lief, G. R; Jordan, R. F. J. Am. Chem. Soc. 2007, $129,8946-8947$

(20) Kochi, T.; Yoshimura, K; Nozaki, K Dalton Trans. 2006, $25-27$.

(21) Borkar, S.; Newsham, D. K; Sen, A. Organometallics 2008, 27, $3331-3334$.

(22) Nakamura, A.; Munakata, K.; Kochi, T.; Nozaki, K. J. Am. Chem. Soc. 2008, 130, 8128-8129.

(23) For a related multinuclear system producing high-molecularweight linear polyethylene see: Shen, Z.; Jordan, R. F. J. Am. Chem. Soc. $2010,132,52-53$.

(24) Downing, J. H.; Smith, M. B. In Comprehensive Coordination Chemistry II; McCleverty, J. A., Meyer, T. J., Eds.; Pergamon: Oxford, U.K, 2003; pp 253-296.

(25) Grushin, V. V. Chem. Rev. 2004, 104, 1629-1662.

(26) Slone, C. S.; Weinberger, D. A.; Mirkin, C. A. In Progress in Inorganic Chemistry; Wiley: New York, 2007; pp 233-350.

(27) (a) Keim, W,; Maas, H.; Mecking, S. Z. Naturforsch., B 1995, S0, 430-438. (b) Brassat, I.; Keim, W.; Killat, S.; Mothrath, M.; Mastrorilli, P.; Nobile, C. F.; Suranna, G. P. J. Mol. Catal. A 2000, $157,41-58$

(28) Mecking, S.; Keim, W. Organometallics 1996, 15, 2650-2656.

(29) Denmark, S. E.; Smith, R. C.; Tymonko, S. A. Tetrahedron 2007, $63,5730-5738$.

(30) Xiaozhong, L.; Hongmei, L.; Fanzhi, K. J. Organomet. Chem. 2002, 664, 1-4.

(31) Billington, D. C.; Malcolm Helps, I.; Pauson, P. L.; Thomson, W.; Willison, D. J. Organomet. Chem. 1988, 354, 233-242.

(32) Ostoja Starzewski, K. A.; Witte, J. Angew. Chem., Int. Ed. 1987, $26,63-64$.

(33) Beach, D. I.; Harrison, J. J. U.S. Patent 4293727, 1981.

(34) In Comprehensive Coordination Chemistry; Wilkinson, G., Gillard,

R. D., McCleverty, J. A., Eds.; Pergamon: Oxford, U.K., 1987.

(35) $\chi$ is defined as the difference between the $A_{1} \nu(\mathrm{CO})$ absorption of $\mathrm{LNi}(\mathrm{CO})_{3}$ and the $\mathrm{A}_{\mathrm{I}} \nu(\mathrm{CO})$ absorption for $(t-\mathrm{Bu})_{3} \mathrm{PNi}(\mathrm{CO})_{3}$.

(36) Tolman, C. A. Chem. Rev. 1977, 77, 313-348.

(37) Wilson, M. R; Woska, D. C.; Prock, A.; Giering, W. P. Organometallics 1993, 12, 1742-1752.

(38) It can be assumed that the steric influence is not as prominent as implied by the cone angles, since the distance between the metal center and palladium is significantly elongated by the oxygen atom. Note that for $\mathrm{OP}\left(3,5-\mathrm{CF}_{3} \mathrm{C}_{6} \mathrm{H}_{3}\right)_{3}$ no parameter data were available but that the coordination strength can be expected to be rather low due to increased steric bulk and electron deficiency in comparison to those of $\mathrm{OP}\left(p-\mathrm{CF}_{3} \mathrm{C}_{6} \mathrm{H}_{4}\right)$.

(39) Derencsenyi, T. T. Inorg. Chem. 1981, 20, 665-670.

(40) Data for $\mathrm{OP}\left(3,5-\left(\mathrm{CF}_{3}\right)_{2} \mathrm{C}_{6} \mathrm{H}_{3}\right)_{3}$ are not available, but the steric bulk is believed to be similar to that of $\mathrm{OP}\left(3,5-(\mathrm{Me})_{2} \mathrm{C}_{6} \mathrm{H}_{3}\right)_{3}$ : Ullrich,
M.; Lough, A. J; Stephan, D. W. Organometallics 2010, 29, $3647-$ 3654.

(41) Note that the exact coordination mode of dmso remains unclear but that for a related complex a $\mathrm{S}$-coordination was observed by $\mathrm{X}$-ray analysis. ${ }^{13}$

(42) In a related study $K_{\mathrm{L}}$ was determined vs dmso for ethyl acetate $\left(K_{\mathrm{EA}}<10^{-2}\right)$, methyl ethyl sulfone $\left(K_{\mathrm{MES}}<10^{-2}\right)$, propionic acid $\left(K_{\mathrm{PrA}}<\right.$ $0.1), N, N$-dimethylacetamide $\left(K_{\mathrm{DMACA}} \approx 0.4\right), N$-methylacetamide $\left(K_{\text {MACA }} \approx 0.6\right)$, and acrylonitrile $\left(K_{A C N} \approx 1\right) .{ }^{9}$

(43) Newsham, D. K.; Borkar, S.; Sen, A.; Conner, D. M.; Goodall, B. L. Organometallics 2007, 26, 3636-3638.

(44) Rünzi, T.; Guironnet, D.; Göttker-Schnetmann, I.; Mecking, S. J. Am. Chem. Soc. 2010, 132, 16623-16630.

(45) Burford, N. Coord. Chem. Rev. 1992, 112, 1-18.

(46) For an example of $\mathrm{OPPh}_{3}$ and $\mathrm{OPBu}_{3}$ coordination toward lanthanides and the resulting changes in ${ }^{31} \mathrm{P} N M R$, IR, and X-ray data see: Deacon, G. B.; Fallon, G. D.; Forsyth, C. M.; Gatehouse, B. M.; Junk, P. C.; Philosof, A.; White, P. A. J. Organomet. Chem. 1998, 565, 201-210.

(47) Cotton, F. A.; Barnes, R. D.; Bannister, E. J. Chem. Soc. 1960, 2199-2203.

(48) Jones, C. J.; McCleverty, J. A.; Rothin, A. S.; Adams, H.; Bailey, N. A. J. Chem. Soc., Dalton Trans. 1986, 2055-2061.

(49) Brock, C. P.; Schweizer, W. B.; Dunitz, J. D. J. Am. Chem. Soc. $1985,107,6964-6970$.

(50) The crystal structure of free $\mathrm{OPPh}_{3}$ has been determined several times for different crystal modifications and at different temperatures, resulting in a bond range from $1.46(1)$ to $1.494 \AA$. For comparison see: Bandoli, G.; Bortolozzo, G.; Clemente, D. A; Croatto, U.; Panattoni, C. J. Chem. Soc. A 1970, 2778-2780. Speck, A. L. Acta Crystallogr., Sect. C: Cryst. Struct. Commun. 1987, 43, 1233-1235. AlFarhan, K. A. J. Chem. Crystallogr. 1992, 22, 687-689. Thomas, J. A.; Hamor, T. A. Acta Crystallogr., Sect. C: Cryst. Struct. Commun. 1993, 49, 355-357.

(51) Note that in these cases only the disappearance of the $\nu(\mathrm{O}=\mathrm{P})$ band of uncoordinated $\mathrm{OPR}_{3}$ is observable; the detection of a new band for coordinated $\mathrm{OPR}_{3}$ is hampered by numerous overlapping $\nu\left(\mathrm{P}^{\wedge} \mathrm{O}\right)$ ligand bands.

(52) An analogous but stepwise transformation could be observed by washing the solid material several times with pentane and recording $I R$ spectra intermittently (cf. Supporting Information).

(53) The compound 1-DMF shows a similar decomposition towards 1 , see ref 9 .

(54) For IR analysis of Pd complexes exhibiting sulfonic acid coordination see: Coles, S. J.; Edwards, P. G.; Hursthouse, M. B.; Abdul Malik, K. M.; Thick, J. L.; Tooze, R. P. J. Chem. Soc, Dalton Trans. 1997, 1821-1830

(55) Note that the initial ${ }^{(\mathrm{P} \wedge \mathrm{O})} \mathrm{OMe} \mathrm{OPR}_{3}$ ratio at $t=0$ is $5: 9$ and deviates from the expected 6:9 ratio. This can be explained by (a) the excess of $\mathrm{OPR}_{3}$ used in the synthesis and (b) a decomposition process already starting during preparation and handling of the NMR sample

(56) Note that 1 cannot be obtained from $\mathbf{1}_{n}$, since the latter does not dissolve in noncoordinating solvents: e.g., $\mathrm{CH}_{2} \mathrm{Cl}_{2}$.

(57) For $\mathrm{L}=$ dmso the equilibrium constants at $80{ }^{\circ} \mathrm{C}$ have been estimated from experiments to be $K_{\mathrm{A}, \mathrm{dms}, 800^{\circ} \mathrm{C}}\left(\approx K_{\mathrm{B}} \approx K_{\mathrm{D}}\right)=1.1 \times$ $10^{-3}, K_{\mathrm{C} 1, d m s 0,80^{\circ} \mathrm{C}}=1.9$, and $K_{\mathrm{C} 2, \text { dmso, } 800^{\circ} \mathrm{C}}\left(=K_{\mathrm{A}} K_{\mathrm{C} 1}\right)=2 \times 10^{-3} .{ }^{18}$ For $\mathrm{L}=\mathrm{OPPh}_{3}$, with the binding strength of $\mathrm{OPPh}_{3}$ vs dmso at $80{ }^{\circ} \mathrm{C}$ being $3.5 \times 10^{-1}$, equilibrium constants are calculated to be $K_{\mathrm{A}, \mathrm{OPPh}} 80^{\circ} \mathrm{C}\left(\approx K_{\mathrm{B}} \approx K_{\mathrm{D}}\right)=3.1 \times 10^{-3}, K_{\mathrm{Cl}_{1}, \mathrm{OPPh}_{3} 80^{\circ} \mathrm{C}}=6.7 \times 10^{-1}$, and $K_{\mathrm{C}, \mathrm{OPPh}_{4}, 80{ }^{\circ} \mathrm{C}}\left(=K_{\mathrm{A}} K_{\mathrm{Cl}}\right)=2 \times 10^{-3}$.

(58) Armarego, W. L.; Perrin, D. D. Purification of Laboratory Chemicals, 4th ed.; Elsevier: Burlington, 1996.

(59) De Graaf, W.; Boersma, J.; Smeets, W. J. J.; Spek, A. L.; van Koten, G. Organometallics 1989, 8, 2907-2917.

(60) Salo, E. V.; Guan, Z. Organometallics 2003, 22, 5033-5046.

(61) Drent, E.; Dijk, R. v.; Ginkel, R. v.; Oort, B. v.; Pugh, R. I. Chem. Commun. 2002, 964-965.

(62) Sheldrick, G. M. SHELXS-97, Program for Crystal Structure Analysis; Universität Göttingen, Göttingen, 1986. 
(63) Sheldrick, G. M. SHELXL-97, Program for Crystal Structure Refinement; Universität Göttingen, Göttingen, 1997. 